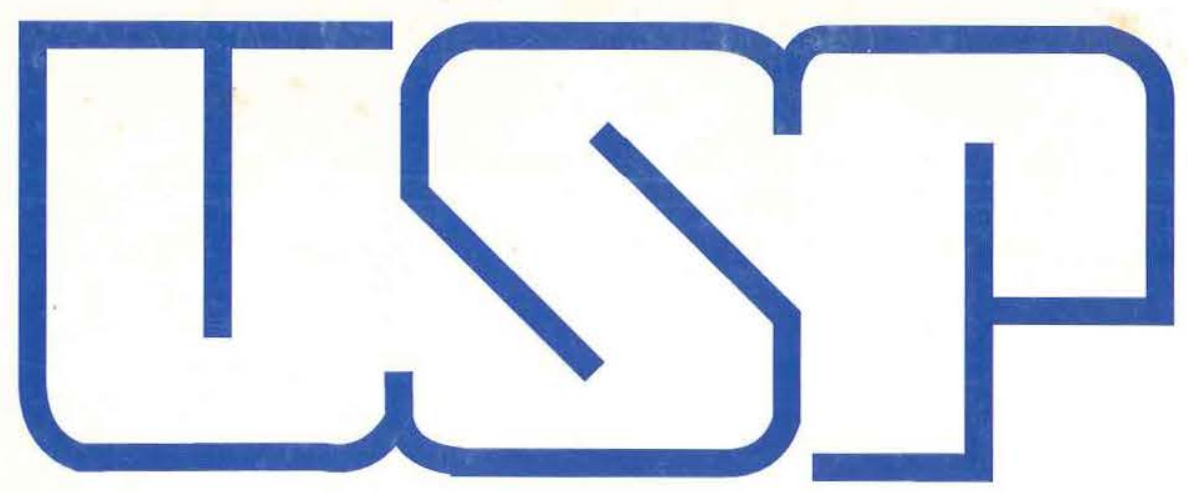

Aplicação do Ultra-Som Terapêutico na cartilagem de Crescimento Proximal da Tíbia de Coelho .

Autora: Andréa Licre Pessina Orientador: Prof. Dr. José B. Volpon

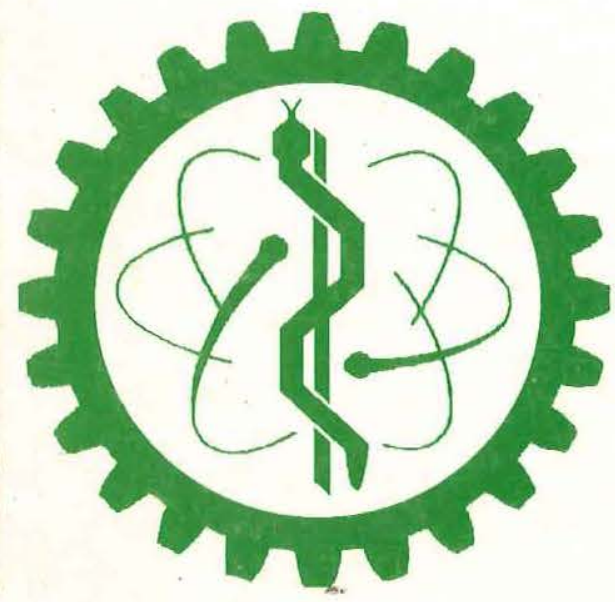

B I O E N G EN HAR I A U S P

Curso de Pós-Graduação Interunidades Bioengenharia

Escola de Engenharia de São Carlos Faculdade de Medicina de Ribeirão Preto Instituto de Química de São Carlos 


\title{
APLICAÇÃO DO ULTRA-SOM TERAPÊUTICO NA CARTILAGEM DE CRESCIMENTO PROXIMAL DA TÍBIA DE COELHO
}

\author{
Andréa Licre Pessina
}

Dissertação apresentada à Escola de Engenharia de São Carlos e Faculdade de Medicina de Ribeirão Preto da Universidade de São Paulo, como parte dos requisitos para obtenção do título de Mestre em Bioengenharia

ORIENTADOR: Prof. Dr. José B. Volpon

Ribeirão Preto

1998 


\section{Osen. TESE-EESC \\ Orat. \\ Tombo T0286 98}

\section{7}

Ficha Catalográfica elaborada pela Biblioteca Central Campus USP - Ribeirão Preto

Pessina, Andréa Licre

P475 Aplicação do ultra-som terapêutico na cartilagem de crescimento proximal da tíbia de coelho / Andréa Licre Pessina.-- Ribeirão Preto, 1998.

53p.: il.; $30 \mathrm{~cm}$

Dissertação (Mestrado) - Faculdade de Medicina de Ribeirão Preto - Universidade de São Paulo, 1998.

Orientador: Prof. Dr. José B.Volpon

1. Osso - crescimento longitudinal. 2. Cartilagem de crescimento - tratamento. 3. Ultra-som. I. Título. 


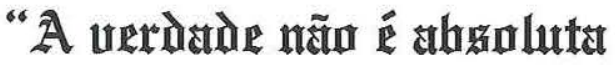

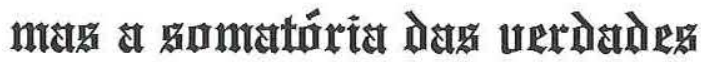
rellattuats". (Lenin) 


\section{Universidade de São Paulo}

Curso de Pós-Graduação Interunidades Bioengenharia

Escola de Engenharia de São Carlos

Faculdade de Medicina de Ribeirão Preto

BIOENGENHARIA

Instituto de Química de São Carlos

Av. Dr. Carlos Botelho, 1465 - C. P. 359 - 13560-970 - São Carlos - SP - BRASIL.

Tel. (016)273-9585 - Fax. (016)273-9586 - Email: bioeng @ sc.usp.br

MEMBROS DA COMISSÃO JULGADORA DA DISSERTAÇÃO DE MESTRADO DA ALUNA ANDRÉA LICRE PESSINA APRESENTADA AO CURSO DE PÓS-GRADUAÇÃO INTERUNIDADES BIOENGENHARIA/EESC/FMRP/IQSC-UNIVERSIDADE DE SÃO PAULO, EM 14/10/1998.

COMISSÄO JULGADORA:
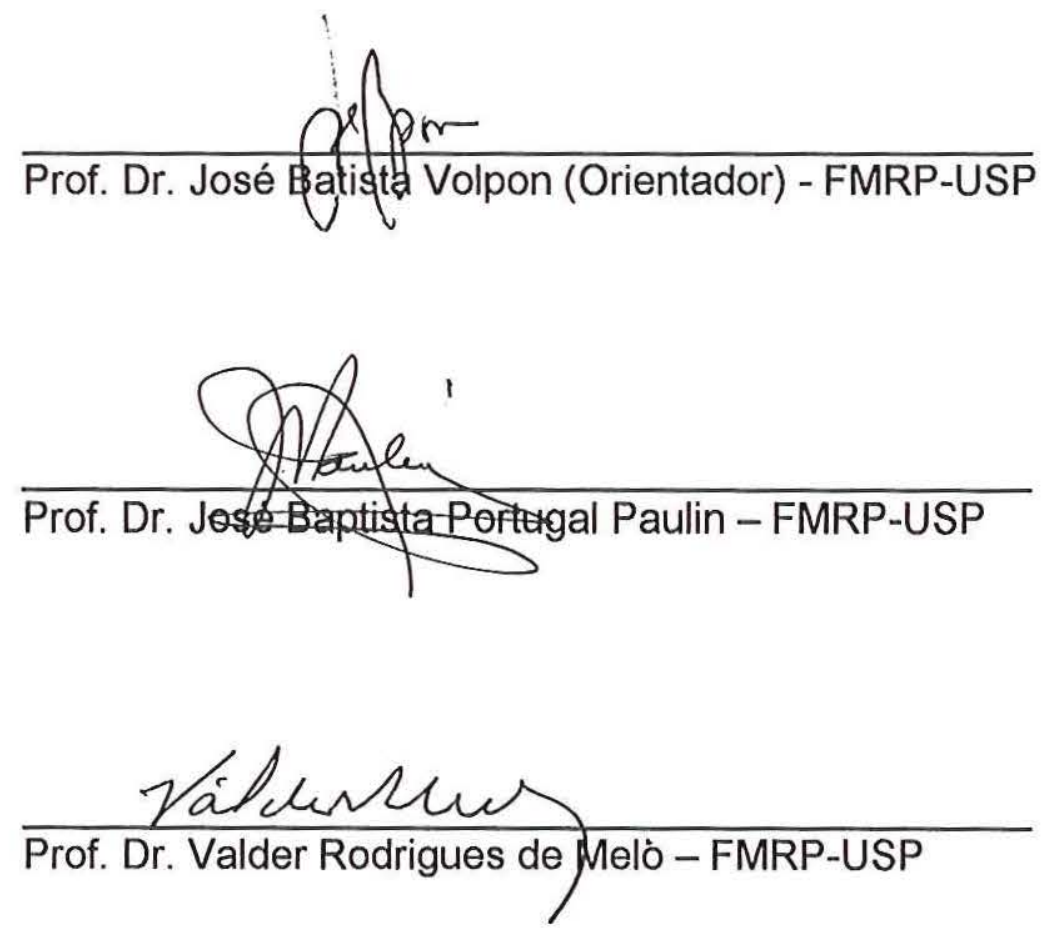


\section{DEDICATÓRIA}

À meus pais José Antônio e Helena

À minha irmã Luciane

À meu noivo Daniel, pessoas

que sempre me incentivaram a superar meus limites 


\section{À Deus, \\ princípio de tudo em minha vida}




\section{AGRADECIMENTO ESPECIAL}

Ao Prof. Volpon, que tomo a liberdade de considerá-lo mais que um orientador mas uma pessoa amiga.

Aceite minha amizade e admiração. 


\section{AGRADECIMENTOS}

À duas pessoas especiais, Sr. Francisco Carlos Mazzocato e Sra. Sônia Ap. da Silva Rodrigues a quem devo reconhecimento pela ajuda inestimável.

Ao Prof. Dr. José B. P. Paulin, como responsável no Laboratório de Bioengenharia, local de realização da pesquisa experimental.

Ao Prof. Dr. Valder Rodrigues de Mello e Prof. Dr. Sérgio Brito Garcia que muito contribuíram com esta pesquisa.

Aos funcionários e amigos do Laboratório de Bioengenharia, Antônio Carlos Shimano, Carlos Alberto Moro, Luis Henrique Alves Pereira e Maria Terezinha de Moraes pela colaboração.

Aos amigos da Pós-Graduação, em especial ao Adriano, Denise, Valdeci e Luciane.

Às amigas Valéria e Marisa incentivadoras e admiradoras do meu trabalho.

À Sra. Rose Pereira Brittes Alves, funcionária do Departamento de Ortopedia e Traumatologia da Faculdade de medicina de Ribeirão Preto pela colaboração em algumas partes deste trabalho.

À Fapesp, Fundação de Amparo à Pesquisa do Estado de São Paulo pela concessão de Bolsa de Mestrado por quinze meses.

À todos que direta ou indiretamente contribuíram para a realização deste trabalho. 


\section{SUMÁRIO}

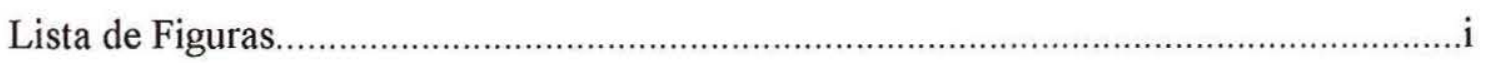

Lista de Tabelas.............................................................................................................ii

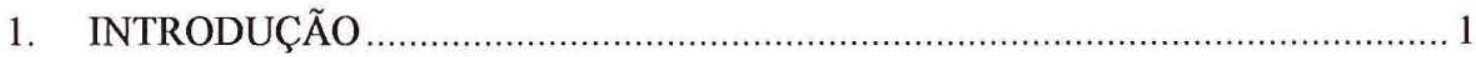

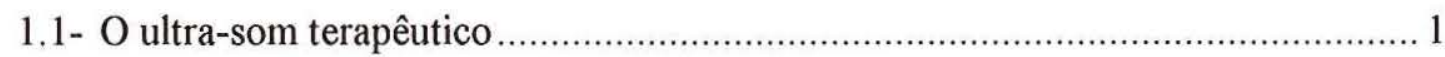

1.2- Efeitos biofísicos e biológicos do ultra-som.................................................... 6

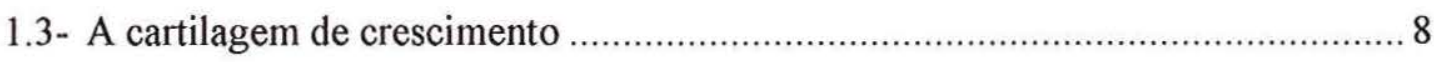

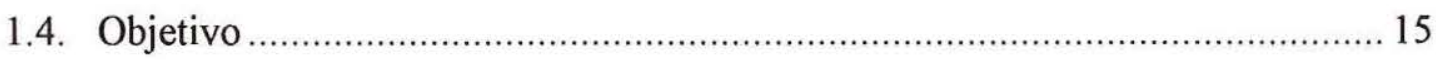

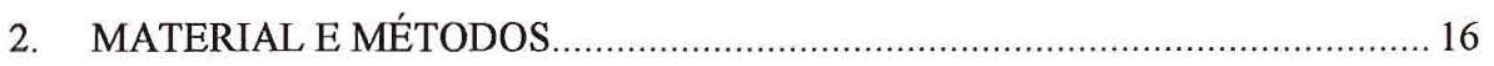

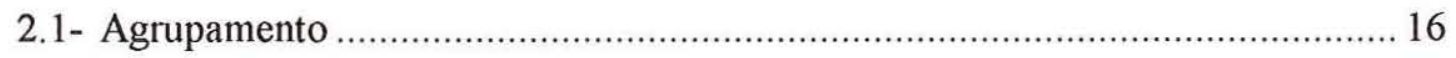

2.2. Técnica de Aplicação do Ultra-som Terapêutico ….......................................... 16

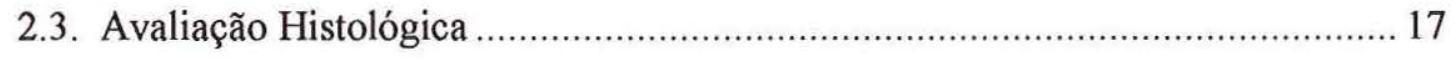

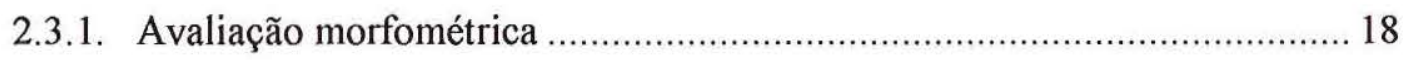

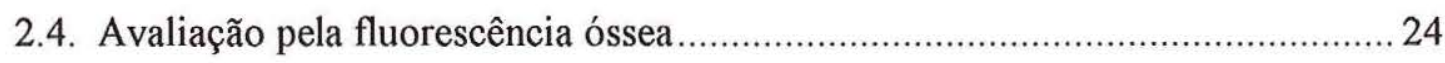

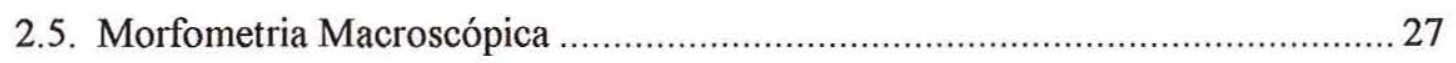

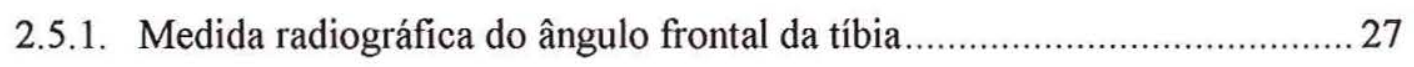

2.5.2. Medidas morfológicas no próprio osso …................................................... 28

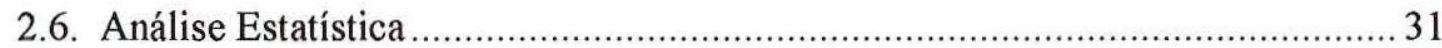

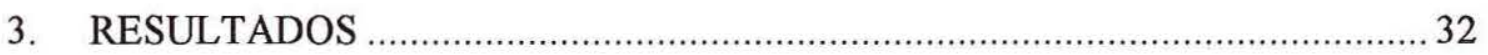

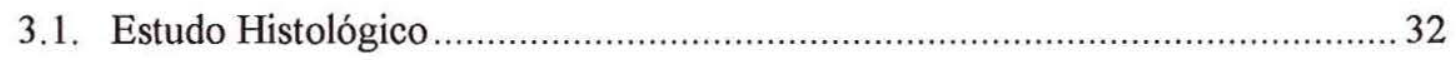

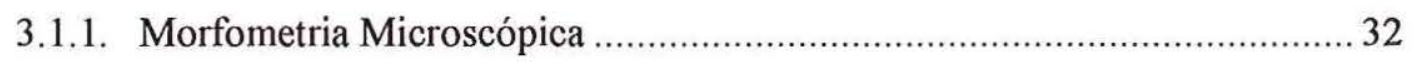

3.1.2 . Estudo Quantitativo por Contagem de Pontos ......................................... 36

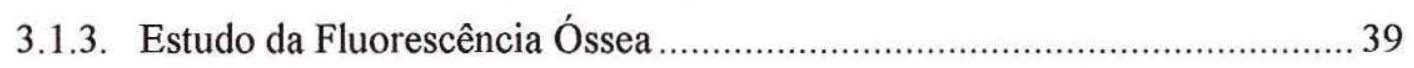

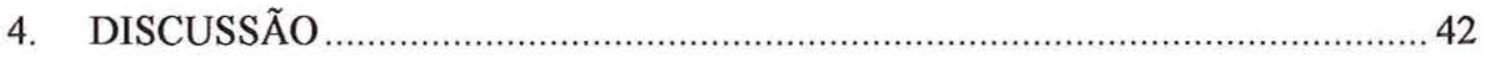

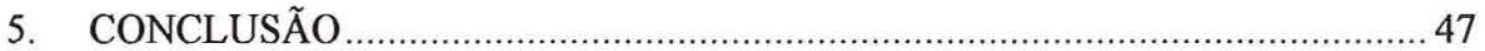

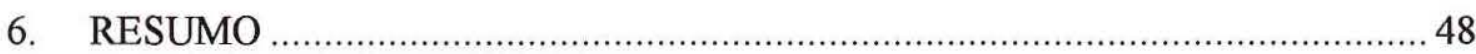

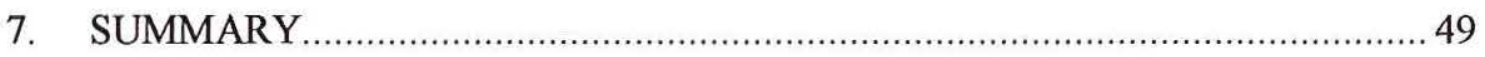

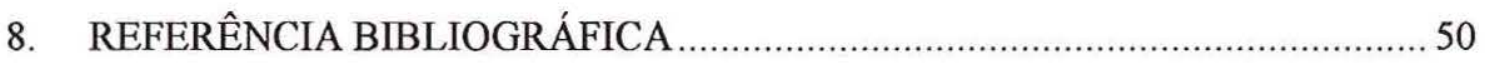




\section{LISTA DE FIGURAS}

Figura 1. Desenho esquemático dos tipos de ondas ultra-sônicas (material baseado no artigo "Therapeutic Ultrasound "ZISKIN et al, In Would Healing Alternatives in Management, 2ed, 1995).

Figura 2.Desenho esquemático ilustrando a formação de ondas estacionárias (material baseado no Manual da KLD, Ultrasom, Fuirini, N. 1996). 3

Figura 3. Desenho esquemático caracterizando as ondas pulsadas (material baseado no artigo "Therapeutic Ultrasound ", ZISKIN et al, 1995). 4

Figura 4. Fotomicrografia de corte frontal da cartilagem de crescimento proximal da tíbia de coelho ilustrando as várias camadas correspondentes ao processo de ossificação endocondral. Caracterização do aspecto seriado da cartilagem cujas células crescem, perdendo progressivamente a organização, aumentando o tamanho impregnando-se com o mineral ósseo (azul alciano-fucsina, $75 \mathrm{x}$ )

Figura 5. Fotomicrografia de corte frontal da cartilagem de crescimento proximal de tíbia de coelho, ilustrando os pontos de referência para as medidas morfométricas ( azul alciano-fucsina, $75 \mathrm{x}$ )

Figura 6. Fotomicrografia da área ocupada pelas diferentes camadas da cartilagem de crescimento que recebeu a placa de pontos eqüidistantes para a contagem de células e matriz.

Figura 7. Fotomicrografia com luz ultra-violeta da cartilagem de crescimento proximal da tíbia de coelho, ilustrando a faixa fluorescente de neoformação óssea marcada pela tetraciclina (seta). A cartilagem de crescimento aparece como faixa escura (seta), (77x)

Figura 8. Figura obtida a partir de uma radiografia mostrando o par de fêmures, tíbias e fíbulas ilustrando a obtenção do ângulo frontal da tíbia $(\alpha)$. 28

Figura 9. A- Ilustração das medidas do comprimento de fềmur (a), de tíbia (b), de largura da epífise femural (c ), da epífise tibial (d) e do comprimento ânteroposterior (e). 
Figura 10. Representação gráfica da área global relativa da cartilagem de crescimento nos lados tratado (T) e não tratado (NT).

Figura 11. Representação gráfica das áreas das diferentes camadas da cartilagem de crescimento nos lados tratado (T) e não tratado (NT)

Figura 12. Espessura relativa das camadas da cartilagem de crescimento nos lados tratado (T) e não tratado (NT).

Figura 13. Contagem de pontos nas células nas diferentes camadas da cartilagem de crescimento.

Figura 14 Contagem de pontos na matriz nas diferentes camadas da cartilagem de crescimento.

Figura 15. Representação gráfica das médias aritméticas das distâncias relativas entre a cartilagem de crescimento e a banda fluorescente 


\section{LISTA DE TABELAS}

Tabela I.- Medidas da área relativa global e das camadas da secção da cartilagem de crescimento nos lados tratados e não tratados. 32

Tabela II - Espessura relativa das diferentes camadas da cartilagem de crescimento nos lados tratado e não tratado. 34

Tabela III - Contagem de pontos nas células nas diferentes camadas da cartilagem de crescimento.

Tabela IV - Contagem de pontos na matriz nas diferentes camadas da cartilagem de crescimento.

Tabela V-Médias aritméticas das distâncias relativas entre a cartilagem de crescimento e a banda fluorescente. 39

Tabela VII -Área e perímetro da seç̧ão transversal epifisiometafisário das tíbias. 41

Tabela VIII - Medida radiológica do ângulo frontal da tíbia 41 


\section{INTRODUÇÃO}

\subsection{O ULTRA-SOM TERAPÊUTICO}

O ultra-som é um recurso de grande valia fisioterápica e diagnóstica. Na terapêutica é um dos principais senão o principal recurso eletroterápico utilizado na rotina clínica. Tem sido utilizado em larga escala no tratamento das mais diversas condições clínicas como desordens músculo-esqueléticas agudas e crônicas (GAM \& JOHANNSEN,1995), cicatrização de úlceras (DYSON et al, 1968), reparo ósseo (DUARTE \& XAVIER, 1983), aumento da circulação sangüínea em tecidos isquêmicos (DYSON, 1985), processos patológicos ortopédicos diversos e como recurso antiinflamatório.

O termo ultra-som é usado para descrever perturbações mecânicas, do meio onde é aplicado, que se propagam de um ponto para outro através de ondas, cuja freqüência de repetição encontra-se acima de $20 \mathrm{KHz}$, tornando-as inaudíveis ao ouvido humano (HILL, 1968).

Por terapia ultra-sônica entende-se o tratamento mediante vibrações mecânicas desta freqüência. Para a propagação é necessário um meio material. Dessa maneira, a propagação ocorre como uma perturbação na posição de equilíbrio das partículas que executam movimentos oscilatórios sem que o meio propriamente dito sofra qualquer deslocamento permanente. O movimento oscilatório assemelha-se, por exemplo, ao comportamento de uma bóia sobre uma superfície aquosa, em que se atira uma pedra (SILVA, 1994).

As ondas ultra-sônicas são geradas por transdutores que são dispositivos que convertem energia elétrica em mecânica. $\mathrm{O}$ som acima da freqüência auditiva humana normalmente é produzido por vibrações (HOOGLAND, 1986). No caso do ultra-som, ocorre a vibração de um cristal de material piezoelétrico que, frente a um campo elétrico, interage com ele e produz tensão mecânica desencadeando, assim, a 
transmissão de ondas ultra-sônicas. As ondas são longitudinais e consistem de um movimento de vai-e-vem de partículas na mesma direção em que se propagam e requerem um meio material de propagação. A direção da onda longitudinal é paralela à direção do feixe originário do cabeçote, tendo como característica compressão e expansão no meio onde transita e conduzindo a variação de pressão (HOOGLAND, 1986).

As vibrações ultra-sônicas também podem se apresentar como ondas transversais. A movimentação das partículas é perpendicular à direção de propagação das ondas (Fig. 1). Entretanto, as ondas transversais são amortecidas de maneira extremamente rápida em líquidos e tecidos moles, não representando um sistema importante de propagação nestes meios e, sim, em meios sólidos como o tecido ósseo.
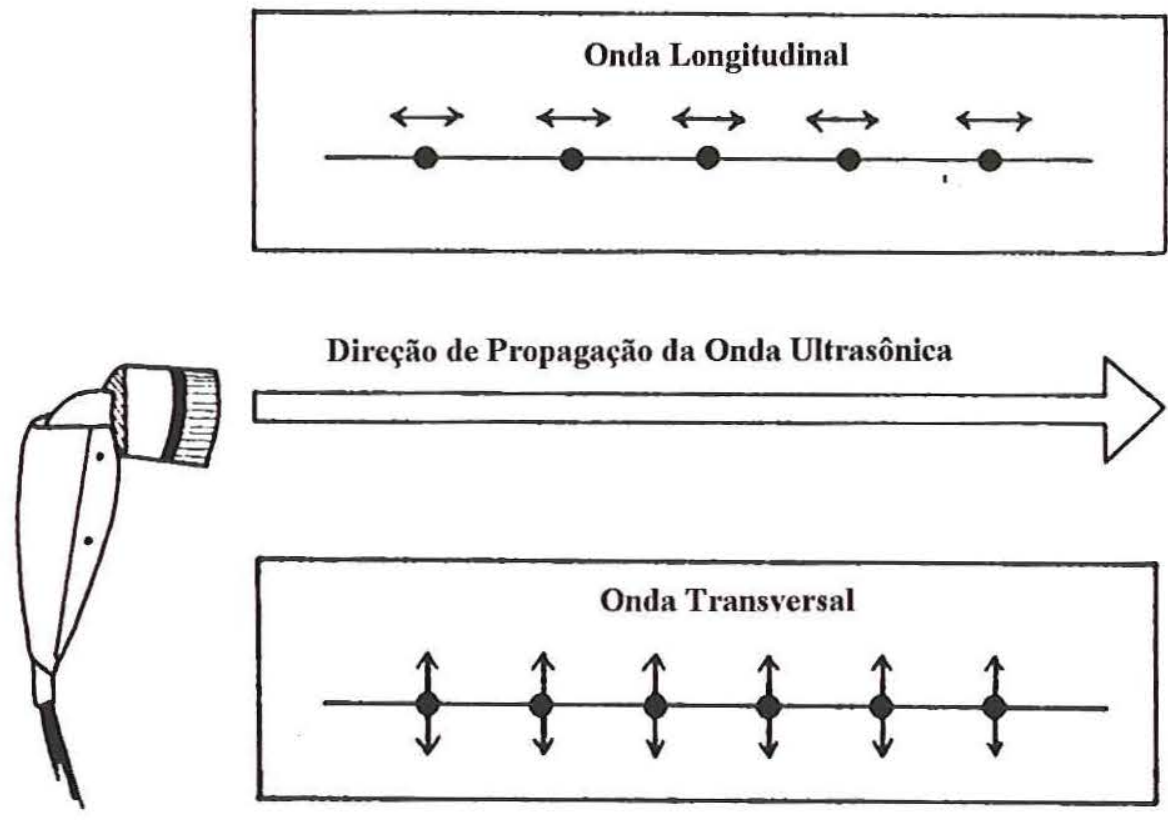

Figura 1. Desenho esquemático dos tipos de ondas ultra-sônicas (material baseado no artigo "Therapeutic Ultrasound "ZISKIN et al, In Would Healing Alternatives in Management, 2ed, 1995) 
Pode ocorrer, ainda, a existência de ondas estacionárias. Neste caso, duas ou mais ondas podem combinar-se formando uma nova onda. São produzidas quando a onda incidente na interface interfere na onda refletida superpondo-se a tal ponto que seus picos de intensidade sejam somados (Fig.2).

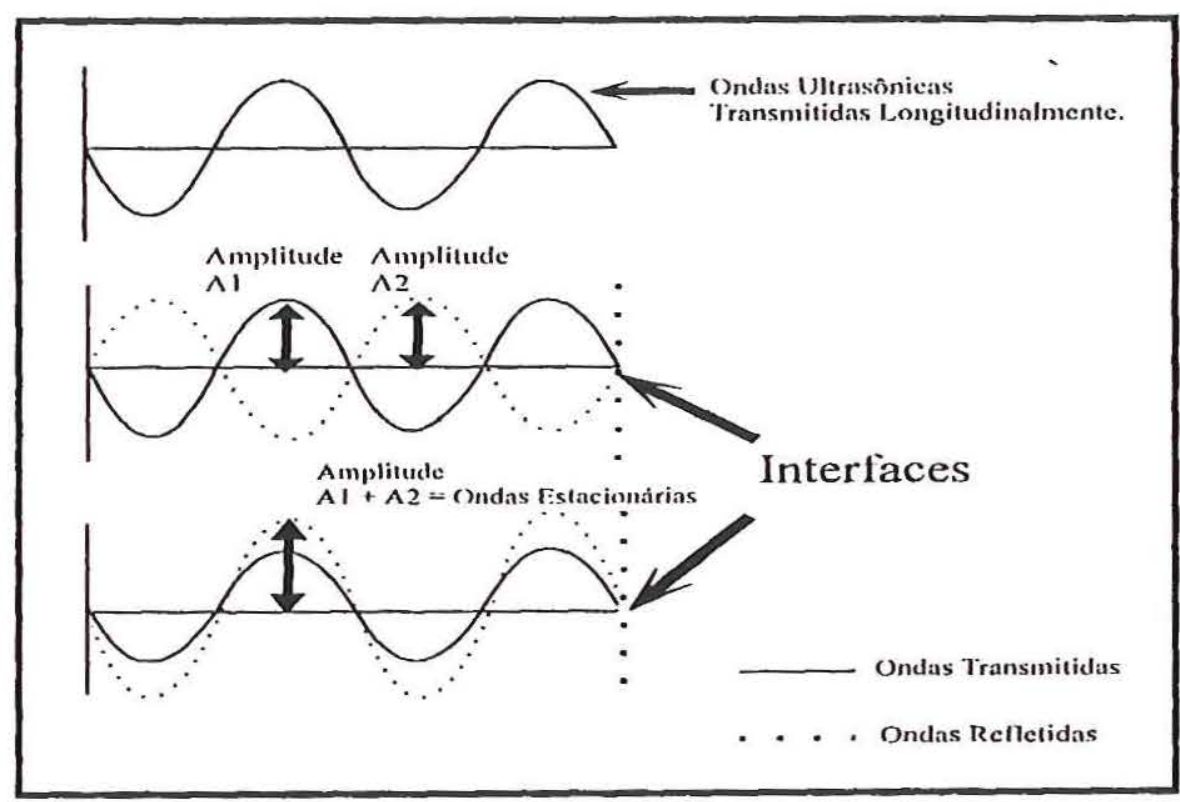

Figura 2.Desenho esquemático ilustrando a formação de ondas estacionárias (material baseado no Manual da KLD, Ultrasom, Fuirini, N. 1996)

As ondas ultra-sônicas terapêuticas podem ser geradas de forma contínua ou pulsadas (HILL, 1968). No modo contínuo a intensidade mantém-se constante, produzindo efeitos térmicos e não térmicos que são controlados pelo fator intensidade.

O modo pulsado apresenta breves interrupções na intensidade sonora mantendo a freqüência sem alteração (PATRICK, 1978) e caracterizando um ciclo de trabalho que apresenta a seguinte equação:

Ciclo de trabalho(\%) $=$ tempo de duração do pulso $X 100$ período 


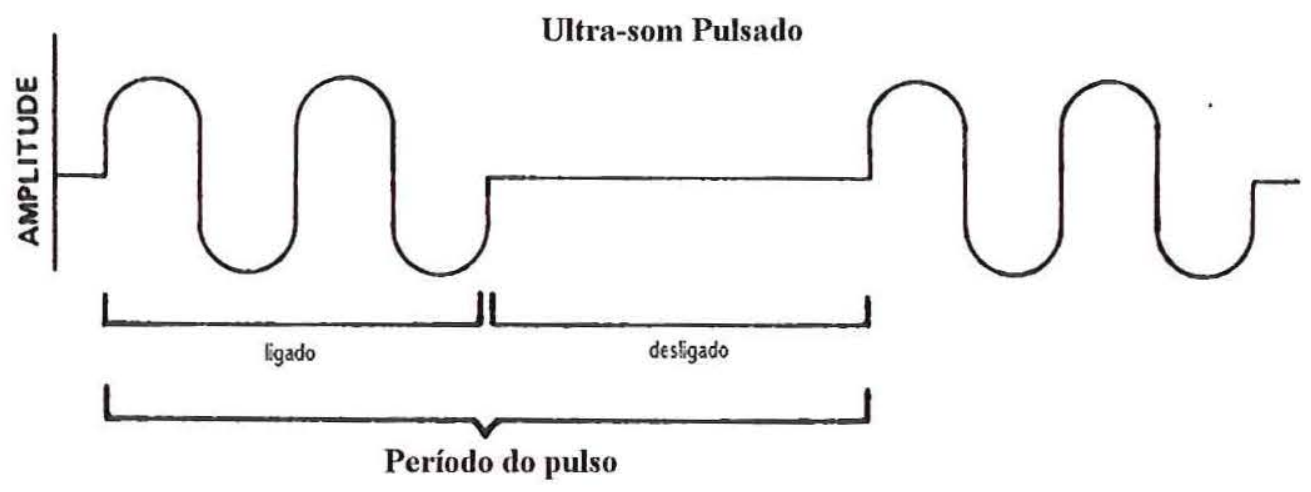

Figura 3. Desenho esquemático caracterizando as ondas pulsadas (material baseado no artigo "Therapeutic Ultrasound ", ZISKIN et al, 1995).

O ultra-som pulsado foi introduzido para o uso terapêutico em 1960 para otimizar efeitos e minimizar riscos (GAM \& JOHANNSEN, 1995). O modo pulsado oferece a vantagem de suprimir as sensações térmicas, portanto, permite o uso de uma intensidade mais alta. $\mathrm{O}$ que existe devido às pulsações são os efeitos mecânicos mais acentuados (HOOGLAND, 1986). A escolha entre forma contínua ou pulsada depende dos fatores físicos e o tipo de interação entre o ultra-som e o tecido (McDIARMID \& BURNS, 1987). O importante de toda escolha é a precaução contra as lesões teciduais como as provocadas pelo calor excessivo, cavitação e ondas estacionárias (McDIARMID et al, 1987).

O ultra-som, enquanto recurso terapêutico, utiliza a capacidade do campo acústico de gerar calor local. As propriedades acústicas de um meio podem ser caracterizadas por parâmetros, como:

- parâmetro de atenuação: relacionado com a redução da intensidade do feixe de ultra-som e o aumento da distância em relação ao transdutor. 
- parâmetro de absorção: prediz a dissipação de energia no tecido e permite o cálculo do incremento da temperatura.

- velocidade do som: permite avaliar distâncias e calcular a refração.

- impedância acústica: permite a análise da transmissão e reflexão do ultra-som em interfaces.

A impedância acústica refere-se a dificuldade que o meio fornece para a transmissão da onda. É própria do tecido que recebe a onda ultra-sônica e depende da densidade do material e da velocidade de propagação. A passagem das ondas ultrasônicas através do material é função da impedância acústica do tecido (HOOGLAND, 1986).

À medida que se propaga através dos tecidos o ultra-som apresenta diferentes comportamentos como atenuação, absorção, reflexão, refração.

A atenuação compreende uma diminuição na amplitude e intensidade das ondas ultra-sônicas à medida que elas passam através de qualquer meio, perdendo energia com a penetração no tecido (HAAR, 1978). Está intimamente relacionado com a impedância acústica.

A absorção das ondas ultra-sônicas ocorre em nível molecular e acontece quando a energia vibracional é transformada em movimentos moleculares aleatórios. Existe absorção de energia nos ligamentos, cápsulas articulares, tendões, proteínas musculares e hemoglobina (FUIRINI, 1996). Este comportamento a que as ondas ultra-sônicas estão sujeitas resulta em aquecimento do tecido justificando, portanto, que tecidos com maior conteúdo protéico aqueçam-se mais que os tecidos adiposos e epiteliais (LEHMANN, \& JOHNSON, 1958). Fatores como impedância acústica e densidade do tecido também interferem na absorção pelo tecido.

A reflexão ocorre nos limites entre os tecidos diferentes (HOOGLAND, 1986). Quando a impedância acústica dos meios for diferente irá promover a reflexão onde a quantidade de energia refletida depende da diferença de impedância acústica dos meios. As principais interfaces biológicas a se considerar são:

- osso/periósteo: podendo apresentar um índice de reflexão de até 30\%. 
- osso/tecido mole: a reflexão sendo grande no osso causa aquecimento extra nos tecidos musculares vizinhos levando, com isto, ou a efeitos terapêuticos ou ao superaquecimento.

- tecido/ ar

- cabeçote transdutor/ ar

- interface tecido conjuntivo

A quantidade de reflexão depende da diferença de impedância acústica de um meio para outro, da freqüência de ocorrência onde, maior a freqüência, maior a reflexão e depende, ainda, da espessura da inteface.

A refração corresponde a um desvio da onda de som nas várias intefaces dos tecidos. A onda de som penetra no tecido a um ângulo de incidência e sai destes tecidos com um ângulo de refração. $\mathrm{O}$ importante é que o feixe ultra-sônico deverá ser aplicado sempre perpendicularmente à superfície de tratamento pois uma inclinação maior que $15^{\circ}$ provoca um ângulo de refração de maneira tal que a onda incidente terá parte refletida e o restante refratado em direção paralela à superficie tornando o tratamento inócuo (FUIRINI, 1996).

\section{2- EFEITOS BIOFÍSICOS E BIOLÓGICOS DO ULTRA-SOM}

A terapia ultra-sônica pode causar vários efeitos fisiológicos, genericamente divididos em térmicos e mecânicos.

$\mathrm{O}$ primeiro efeito detectado do encontro das ondas ultra-sônicas com o tecido corporal certamente é o de natureza mecânica. As vibrações ultra-sônicas causam compressão e expansão do tecido. Esse efeito também é conhecido como micromassagem (HOOGLAND, 1986). Os efeitos térmicos, gerados pela absorção da energia sonora em forma de calor (BALDES ; HERRICK ; STROEBEL, 1958) podem ser divididos em térmicos e não-térmicos (KITCHEN, \& PARTRIDGE, 1990). A ocorrência destes efeitos está diretamente relacionada com fatores como a duração do tratamento, intensidade, freqüência e tipo de ondas e coeficiente de absorção (DYSON, 
1987). Alguns fatores podem ser controlados como o tipo de onda (contínua ou pulsada), a intensidade e a duração do tratamento. A quantidade de calor gerada pelo efeito térmico difere nos vários tecidos. No organismo humano submetido a condições terapêuticas, a distribuição da temperatura e os locais de seu aumento dependem da propagação e absorção do ultra-som através dos tecidos e alteração frente as respostas fisiológicas ao calor (LEHMANN; DeLATEUR; SILVERMAN, 1966). Para a obtenção das respostas físiológicas geradas pelo efeito térmico a temperatura produzida pelas ondas ultra-sônicas deve gerar em torno de $40^{\circ} \mathrm{C}$ a $45^{\circ} \mathrm{C}$ durante o tempo de aplicação. Isto pode produzir aumento temporário na extensibilidade das estruturas colagenosas como os tendões, ligamentos e cápsulas reduzindo, assim, dores, espasmos musculares e limitações articulares (LEHMANN \& GUY, 1972). As temperaturas acima de $45^{\circ} \mathrm{C}$ são lesivas aos tecidos, e podem ser evitadas se for usado o ultra-som pulsado e aplicada a técnica de movimentação do cabeçote (DYSON, \& SUCKLING, 1978). Os efeitos não térmicos produzem alterações na permeabilidade da membrana e processos de cavitação. Compreende-se por cavitação a formação e crescimento de bolhas de gás que ocorrem nos fluidos corpóreos, células e tecidos, como o tecido ósseo (DYSON \& SUCKLING, 1978). No processo de cavitação podem ser identificadas as formas estável e transiente. No primeiro caso, ocorre a permanência da bolha de gás. No segundo caso, a intensidade acústica é grande o suficiente para provocar o colapso na bolha de gás durante a fase de compressão da vibração (HILL, 1968), quando ocorre a mudança da pressão no campo ultra-sônico (WELLS,1977).

Outro efeito biológico decorrente da aplicação de ondas ultra-sônicas é desencadeado pelas forças de radiação que promovem deslocamento, distorção e/ou reorientação de partículas intercelulares. As novas posições podem não ser biologicamente favoráveis podendo produzir efeitos danosos aos tecidos (OKUNO,1982).

Os vários efeitos provocados pelas ondas ultra-sônicas ocorrem simultaneamente (DYSON, 1982). No entanto, apresentam-se mais intensificados ou não em decorrência do tipo de onda utilizado. 
O ultra-som do tipo contínuo caracteriza-se pela forte produção de efeitos térmicos, que também estão presentes no ultra-som pulsado, porém minimizados devido às pequenas interrupções na transmissão da onda (PATRICK, 1978).

A transferência de energia ultra-sônica obedece a duas técnicas de aplicação. $O$ método de contato direto, utilizado com maior freqüência, consiste na aplicação direta do cabeçote gerador de ondas sobre a área corporal a ser tratada. Sabe-se que o ar reflete quase por completo o ultra-som e as ondas ultra-sônicas não se propagam no vácuo (ALDES, 1956). Portanto, é absolutamente necessária a aplicação de um fator condutor entre o cabeçote e a pele (HOOGLAND, 1986). Freqüentemente utilizam-se géis aquosos para o favorecimento da transmissão de energia ultra-sônica. A segunda técnica compreende a de imersão, onde se utiliza um cabeçote submerso em água que atua como meio acoplador. Esta técnica é utilizada em regiões irregulares, em que o bom contato entre o cabeçote e a pele está prejudicado.

As contra-indicações mais freqüentes à aplicação do ultra-som incluem processos infecciosos, presença de osteossíntese e proximidade da cartilagem de crescimento, quando tratar-se de criança. Ainda, áreas nobres como olhos, áreas com deficit sensitivo ou alterações circulatórias, tumores e hemorragias (LIANZA, 1982).

\section{3- A CARTILAGEM DE CRESCIMENTO}

O osso é responsável por funções biológicas e mecânicas, por exemplo, a proteção de tecidos nobres como o cérebro e o coração e a transmissão de forças originadas pela contração muscular de uma parte do corpo para outra, durante o movimento. Também, é de grande importância metabólica no armazenamento de íons, particularmente cálcio e fósforo (WEISS,1983).

O embrião, após passar pelos dos estágios de blástula e gástrula, durante as primeiras semanas de vida intra-uterina começa, gradativamente, a tomar forma, desenvolvendo cabeça, tronco e saliências externas que constituirão os brotos dos membros. As células mesenquimais contidas entre o ectoderma e endoderma (sáculos 
embrionários) diferenciam-se em diversas estruturas do tecido conjuntivo, incluindo osso e cartilagem (HAM, 1967).

O tecido ósseo é uma variedade de tecido conjuntivo que surge:

a) diretamente no tecido conjuntivo embrionário- ossificação intramembranosa

b) a partir de um modelo preexistente de cartilagem- ossificação endocondral

Na ossificação intramembranosa os osteoblastos e osteoclastos, células do tecido ósseo, aparecem por diferenciação das células mesenquimais preexistentes na área.

$\mathrm{Na}$ ossificação endocondral, as células mesenquimais se diferenciam em condrócitos que proliferam a partir da atividade da cartilagem de crescimento e secretam substância intercelular. Com o decorrer do tempo, a quantidade de matriz intercelular aumenta consideravelmente e os condrócitos passam a produzir fosfatase alcalina e se inicia um processo de calcificação da matriz. Os espaços deixados pelo desaparecimento dos condrócitos é invadido por vasos sangüíneos e células de formação do tecido ósseo (osteoblastos) e células de remodelação deste tecido (osteoclastos).

Com a invasão vascular na região central do osso forma-se o núcleo primário de ossificação que se expandirá na direção das extremidades, no caso de um osso longo.

Em uma etapa seguinte da vida pré-natal, ou mesmo da vida pós-natal, há nova invasão vascular, desta vez na extremidade cartilaginosa do osso provocando, nas epífises, a formação dos núcleos secundários de ossificação. Estes aumentam de tamanho e vão substituindo o tecido cartilaginoso sendo que as fronteiras do núcleo primário e núcleo secundário de ossificação aproximam-se na transição epifisiometafisária, até delimitar uma placa ou lâmina cartilagínea que constituirá a placa de crescimento. Esta estrutura será responsável pelo crescimento longitudinal dos ossos longos.

$\mathrm{Na}$ literatura, a placa de crescimento pode ser reconhecida por vasta sinonímia como cartilagem de crescimento, cartilagem de conjugação, placa epifisária, disco epifisário e outros (GOMES, \& VOLPON, 1991). Tem a função primordial de promover o crescimento longitudinal do osso.

Para que ocorra o crescimento ósseo é necessário que exista vascularização na placa epifisária. Há três grandes vias de suprimento vascular. A artéria epifisária penetra 
o centro de ossificação secundário, seus ramos terminais passam através da zona de reserva cartilagínea. Os vasos nutrientes (ramos artéria nutrícia) entram pela metáfise e seus cordões capilares terminam junto à interface cartilagínea da placa de crescimento. A periferia da placa é suprida pela artéria metafisária. TRUETA \& AMATO (1969) afirmaram que não existem anastomoses entre os vasos epifisários e metafisários através da cartilagem de crescimento, após sua completa definição anatômica. A nutrição das células mais centrais ocorre pela difusão de metabólitos difundidos através da matriz cartilaginosa pelos movimentos articulares intermitentes que promovem aumento e alívio da pressão, gerados pelo apoio do peso corpóreo sobre os ossos e pelas contrações musculares (TRUETA \& MORGAN, 1960).

$\mathrm{O}$ crescimento do osso é resultado de vários processos independentes, porém integrados, envolvendo uma sequência de eventos (INGALLS, 1941).

A cartilagem de crescimento apresenta-se histologicamente estratificada em quatro diferentes camadas ou zonas intimamente relacionadas cujos limites não são bem definidos, havendo a transição nas características de uma zona para outra (HAM,1967).

Analisando-as da epífise para a diáfise as seguintes camadas podem ser identificadas:

a-) Zona de cartilagem em repouso.

Geralmente denominada zona germinativa. Camada junto ao osso subcondral, de pequena espessura, com muita substância intersticial e poucas células distribuídas de maneira esparsa. São células esféricas, existentes em pares ou únicas. Em número, são relativamente poucas quando comparadas ao número de células das outras zonas, e são separadas uma das outras por uma grande quantidade de matriz extracelular. Estudos microscópicos revelaram que essas células contêm abundante retículo endoplasmático e armazenam grande quantidade de lipídeos e glicogênio. Durante o crescimento as células formadas nesta camada são submetidas à diferenciação e entram para a zona proliferativa (LOVERIDGE \& FARQUHARSON,1993). As fibras colágenas dessa zona possuem distribuição e orientação casual. Ainda como característica apresentam baixa concentração de oxigênio, o que sugere que os vasos sangüíneos que percorrem essa zona não são suficientes para a nutrição das células (BRIGHTON,1978). 


\section{b-) Zona de cartilagem proliferativa.}

Caracterizada pela presença de condrócitos alinhados longitudinalmente dispostos em colunas paralelas, separadas por abundante matriz intercelular. Possui a mais alta tensão de oxigênio, sendo esta característica explicada pelo suprimento sangüíneo local, o que suporta o intenso metabolismo aeróbico na área (TRUETA \& MORGAN, 1960). As primeiras células da coluna são verdadeiramente as células-mãe para cada coluna. Segundo os estudos realizados por KEMBER,1960, o crescimento longitudinal na placa de crescimento é igual ao número de divisões celulares multiplicado pelo tamanho máximo da última célula da zona hipertrófica. $\mathrm{O}$ crescimento longitudinal depende do número total de divisões das células-mãe e do número de divisão de cada célula filha. A taxa de divisões pode ser influenciada por fatores mecânicos e hormonais.

A função desta zona relaciona-se com a proliferação celular (BRIGHTON,1978).

\section{c-) Zona de células hipetróficas.}

Células com arranjo colunar de maneira mais desorganizada, caracterizadas pela hipertrofia e pouca substância intercelular. Os condrócitos apresentam-se esféricos e grandes. Estas mudanças são gradativas, dificultando a determinação dos limites de uma zona para outra. Os condrócitos produzem grande quantidade de fosfatase alcalina, importante para a calcificação da matriz extracelular. No início dessa zona ainda existe concentração de glicogênio na célula, porém, perto do meio desta zona o citoplasma perde abruptamente todo o glicogênio. A tensão de oxigênio é baixa, sendo este fato explicado pela falta de vascularização. Sendo assim, o metabolismo aí é anaeróbio. As células, desta zona, têm como função a preparação da matriz para a calcificação e a calcificação propriamente dita caracterizando, assim, a última ação das células, que compreende a morte celular com subseqüente calcificação (IANNOTTI, 1990). 


\section{d-) Zona de cartilagem em calcificação.}

Comporta a matriz cartilaginosa que, progressivamente impregna-se com mineral ósseo. Os capilares com células osteogênicas invadem essa zona favorecendo a chegada dos osteoblastos e deposição de matriz óssea nos resquícios de cartilagem calcifícada (Fig. 4). 


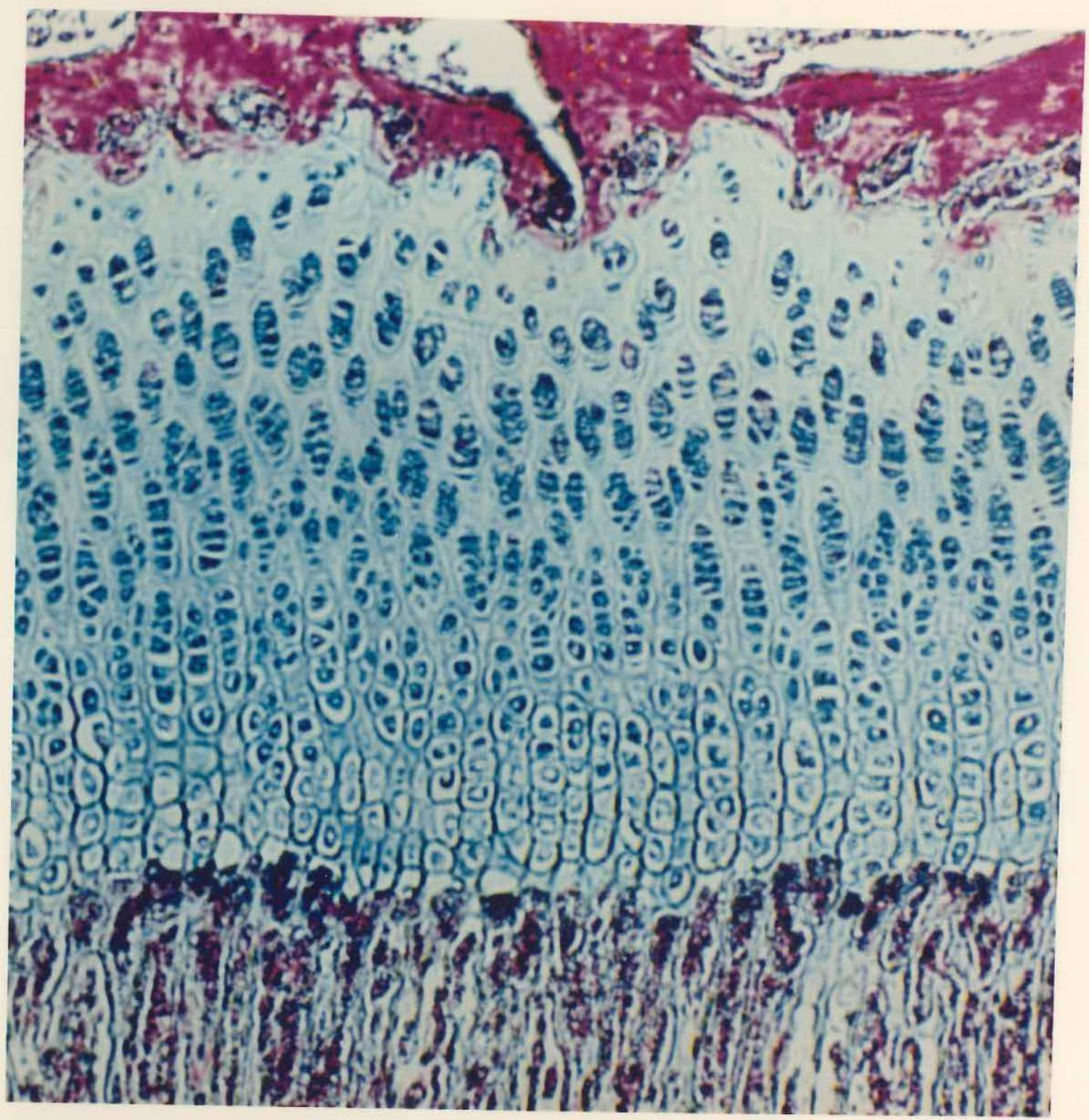

Figura 4. Fotomicrografia de corte frontal da cartilagem de crescimento proximal da tíbia de coelho ilustrando as várias camadas correspondentes ao processo de ossificação endocondral. Caracterização do aspecto seriado da cartilagem cujas células crescem, perdendo progressivamente a organização, aumentando o tamanho impregnando-se com o mineral ósseo (azul alciano-fucsina, 75 x) 
A cartilagem de crescimento, além da função de promover o crescimento longitudinal do osso, também contribui para a distribuição de forças aplicadas na epífise (BRIGHT; BURSTEIN; ELMORE, 1974), estando submetida a esforços de tração, compressão, torção e cisalhamento. Ela representa uma estrutura relativamente frágil do ponto de vista mecânico e, recebendo traumatismos agudos, pode fraturar-se (SALTER \& HARRIS, 1963).

As lesões que acometem a placa de crescimento representam $15 \%$ a $20 \%$ das fraturas na criança e merecem atenção especial por apresentarem seqüelas importantes, quanto a possibilidade de desenvolver distúrbios de crescimento (SALTER \& HARRIS, 1963).

HASS (1917 e 1919) foi um dos primeiros a estudar as lesões na placa de crescimento com ações que a lesavam, como incisões cirúrgicas e esmagamentos. Demonstrou que o distúrbio de crescimento está intimamente ligado ao tipo de lesão, sendo tanto pior quanto mais próximo da camada germinativa e proliferativa. As lesões próximas da transição da camada hipertrófica com a calcificada apresentava, apenas, discreto atraso no crescimento. Cada tipo de lesão apresenta processos reparativos peculiares que poderão interferir com o crescimento futuro (GOMES \& VOLPON, 1988 ; GOMES \& VOLPON, 1993).

A cartilagem de crescimento é um tecido de grande vulnerabilidade quando submetida a forças externas. Quando um corpo está sob a ação de forças externas, apresenta tendência à deformação a que se contrapõe a resistência interna (tensão) contra a deformação experimentada pelo corpo (FONTOURA FILHO,1996).

Estas forças podem provocar, na cartilagem de crescimento, lesões agudas representadas por fraturas, descolamentos, esmagamentos e que apresentarão diferentes prognósticos, de acordo com a zona afetada. Vários são os recursos para o tratamento destes traumas, porém todos visam à recuperação funcional da cartilagem de crescimento na tentativa de se evitar todo ou qualquer distúrbio no crescimento futuro.

A cartilagem de crescimento relaciona-se anatomicamente com outras estruturas como tendões, apófises, bursas e ligamentos e estas estruturas podem ser afetadas principalmente por distensões e esforços repetitivos, dando origem a processos 
inflamatórios localizados provocados pela sobrecarga local. As lesões por esforço podem provocar fraturas apofisárias, osteocondrites, tendinites, bursites, merecendo atenção especial para o tratamento.

Quando, na criança, o processo inflamatório se localiza nas adjacências da cartilagem de crescimento (como freqüentemente acontece) há, na fisioterapia, consenso de que a aplicação de ultra-som esteja contra-indicada por temerem-se danos às células da cartilagem de crescimento. Este conceito tornou-se dogmático, porém suas justificativas têm embasamento predominantemente teórico. Com efeito, há na literatura apenas o trabalho de Wiltink et al (1995) que estudaram o efeito do ultra-som terapêutico pulsado na ossificação endocondral. A investigação foi realizada em cultura de cartilagem e os autores encontraram aumento do crescimento longitudinal por estimulação da zona proliferativa. Entretanto, não há trabalhos semelhantes para comparação de resultados, sejam clínicos ou experimentais.

\subsection{OBJETIVO}

O objetivo deste trabalho foi investigar uma possível influência da aplicação do ultra-som pulsado na cartilagem de crescimento, principalmente do ponto de vista morfológico (microscópico). 


\section{MATERIAL E MÉTODOS}

O experimento foi realizado em 30 coelhas albinas da raça Nova Zelândia, com peso aproximado de $1,0 \mathrm{~kg}$ e fornecidas pelo Serviço de Biotério Geral da Prefeitura do Campus Administrativo de Ribeirão Preto-USP.

Todos os animais receberam aplicação de ultra-som terapêutico na região da cartilagem de crescimento proximal da tíbia direita, segundo técnica a ser descrita, sendo o lado esquerdo sempre mantido como controle. Os métodos de avaliação foram histológicos descritivos e morfométricos.

\section{1- Agrupamento}

Os animais foram divididos em dois grupos, sendo que ambos receberam o mesmo tipo de tratamento. O primeiro grupo, composto de vinte coelhas, foi destinado ao estudo do tratamento em curto prazo e com sacrifício três dias após o término da aplicação do ultra-som.

O segundo grupo, composto de dez coelhas, foi destinado a avaliação tardia do efeito do tratamento, com sacrifício no final do crescimento esquelético do animal.

\subsection{Técnica de Aplicação do Ultra-som Terapêutico}

A região de aplicação do ultra-som foi na face medial da região proximal da perna direita onde a tíbia é de localização subcutânea e a região é plana, permitindo bom acoplamento do transdutor. Comparações realizadas com radiografias mostraram que a periferia da cartilagem de crescimento localiza-se nessa região, adjacente à interlinha articular que é facilmente percebida por palpação e serviu como referencial anatômico.

Previamente, foi realizada tricotomia na região proximal da perna e do joelho direito. Durante as sessões os animais foram imobilizados com contenção manual para que ficassem calmos e confortáveis. 
O aparelho de ultra-som utilizado foi do tipo pulsado, marca KLD Avatar $\mathrm{II}^{\circledR}$ com freqüência de $1 \mathrm{MHz}$, intensidade de $535 \mathrm{~mW} / \mathrm{cm}^{2}\left(0,5 \mathrm{~W} / \mathrm{cm}^{2}\right)$ e pulso de $2: 8$. O aparelho foi previamente calibrado na Escola de Engenharia de São Carlos da Universidade de São Paulo, no Laboratório de Bioengenharia. Todas as sessões transcorreram da mesma forma e sempre foi utilizado o mesmo aparelho.

Cada animal foi tratado uma vez ao dia, durante 5 minutos, por 10 dias consecutivos, sempre no mesmo período do dia.

No último dia de aplicação ultra-sônica, foram injetados $75 \mathrm{mg} / \mathrm{kg}$ peso oxitetraciclina (Terramicina $\left.{ }^{(}\right)$intraperitonialmente em cada animal (FROST, 1963), com o propósito de marcar a neoformação óssea. As tetraciclinas apresentam a capacidade de incorporarem-se definitivamente no osso neoformado no período em que estiverem em circulação (PURAMEN, 1966).

Após 3 dias da última sessão com o ultra-som, os animais foram sacrificados com dose letal de tionembutal injetado endovenosamente. Em seguida, os membros posteriores foram desarticulados nos quadris e tornozelos e o fêmur e tíbia limpos das partes moles, mantendo-se, apenas, a união pelos ligamentos e cápsula articular do joelho.

No grupo para avaliação tardia os animais não receberam oxitetraciclina e foram sacrificados de forma análoga no final do crescimento.

\subsection{Avaliação Histológica}

As tíbias do grupo de 20 animais foram separadas dos fềmures e serradas transversalmente na região diafísária. $\mathrm{O}$ segmento proximal foi fíxado a uma máquina especial para corte de tecidos duros (SHIMANO, PAULIN, TERRA \& PEREIRA, 1990) e seccionado em metades no plano coronal. Da metade anterior, usando a mesma máquina, foi retirada uma seç̧ão óssea de 1,6 mm de espessura, paralela à superfície do corte anterior. Este fragmento foi reduzido no comprimento e destinado ao processamento para estudo da fluorescência óssea. 
A metade posterior da tíbia foi aparada e destinada ao estudo histológico com microscopia de luz comum. Foi fixada em solução de Bouin onde sofreu descalcificação por passagem de corrente elétrica (GONÇALVES \& OLIVÉRIO, 1965). Depois, foi processada de maneira rotineira, fornecendo cortes coronais de 6 micrômetros de espessura, incluídos em parafina, corados pela hematoxilina-eosina e pelo tricrômico azul alciano-fucsina, sendo três cortes de 6 micrômetros de espessura seqüenciais e consecutivos para cada coloração.

Estas lâminas foram examinadas ao microscópio de luz comum, atentando-se especialmente para as características morfológicas da cartilagem de crescimento, aspecto das células, organização das colunas e características da substância intercelular.

\subsubsection{Avaliação morfométrica}

\subsubsection{Determinação da Área e Espessura}

Todas as lâminas foram fotografadas em fotomicroscópio Axiophot ${ }^{\circledR}$, filme ASA 100 e com controle automático do tempo de exposição. Para seleção da área a ser fotografada foi identificada, primeiramente, a região central da cartilagem de crescimento, facilmente localizada por apresentar uma reentrância típica. A partir deste ponto foi selecionada, para a documentação, a área imediatamente adjacente e medial. Esta região foi escolhida para análise por ser aquela que apresenta as camadas celulares mais facilmente identificáveis e com células mais regularmente distribuídas. Foram obtidas cópias fotográficas de tamanho $9 \times 12 \mathrm{~cm}$, o que produziu aumento final de 75 vezes.

Em cada fotografia, no limite epifisário da cartilagem de crescimento, foi selecionada uma extensão de $4 \mathrm{~cm}$ que foi marcada centímetro a centímetro para servir como pontos de referência para as medições. Estes pontos foram denominados, da periferia do corte para a região central, L1, L2, L3 e L4. Depois, foram determinados os pontos de separação entre as camadas germinativa, proliferativa e hipertrófica (Fig.5) 
Para serem analisadas, as fotografias foram tomadas ao acaso, sendo classificadas por código, de modo a não se identificar, no momento da morfometria, a que animal ou a que lado correspondiam. Cada fotografia foi colocada sobre uma mesa de medição gráfica e, com um cursor, fazia-se o delineamento da região de interesse, conforme o parâmetro a ser analisado, sendo os cálculos fornecidos automaticamente pelo programa do aparelho (Mini Mop-Videoplan ${ }^{\circledR}$, Kontrol Eletronik, Alemanha).

Os parâmetros analisados foram: área total da cartilagem de crescimento, área de cada camada da cartilagem de crescimento e espessura total e de cada camada da cartilagem de crescimento, correspondendo às distâncias dos pontos correspondentes do lado epifisário até o lado metafisário, nos pontos demarcados. 


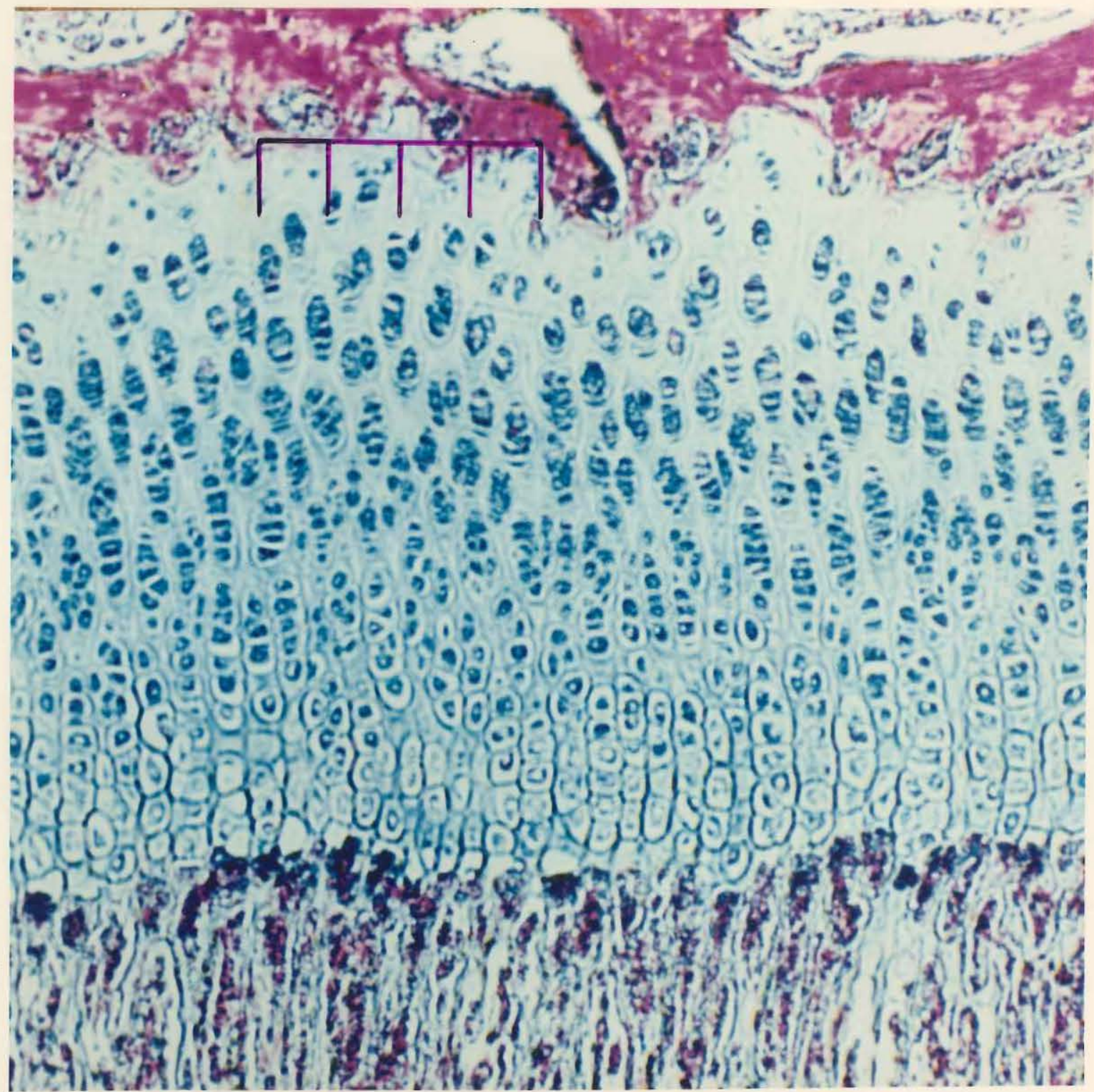

Figura 5. Fotomicrografia de corte frontal da cartilagem de crescimento proximal de tíbia de coelho, ilustrando os pontos de referência para as medidas morfométricas ( azul alciano-fucsina, $75 \mathrm{x}$ ). 


\subsubsection{Análise Quantitativa por Contagem de Pontos.}

Para avaliar a área ocupada por cada diferente zona da cartilagem de crescimento foi realizado um estudo quantitativo de imagens pelo método da contagem de pontos. Todas as lâminas processadas para o estudo histológico foram fotografadas em fotomicroscópio ZEISS 1, filme Tmax Asa 100, objetiva Apo 40 e Optovar 1,25. A placa de crescimento foi fotografada longitudinalmente sempre na direção da diáfise para a epífise (Fig. 6). Foram obtidas cópias em papel fotográfico $12 \times 18 \mathrm{~cm}$, a partir do original (no negativo) de 160 vezes.

Para cada fotomicrografia, que correspondia a cada zona da placa de crescimento, foi avaliada a proporção células / matriz utilizando para isso uma placa de pontos regulares equidistantes contendo 200 pontos (WEIBEL; KISTLER; SCHERLE, 1966). 


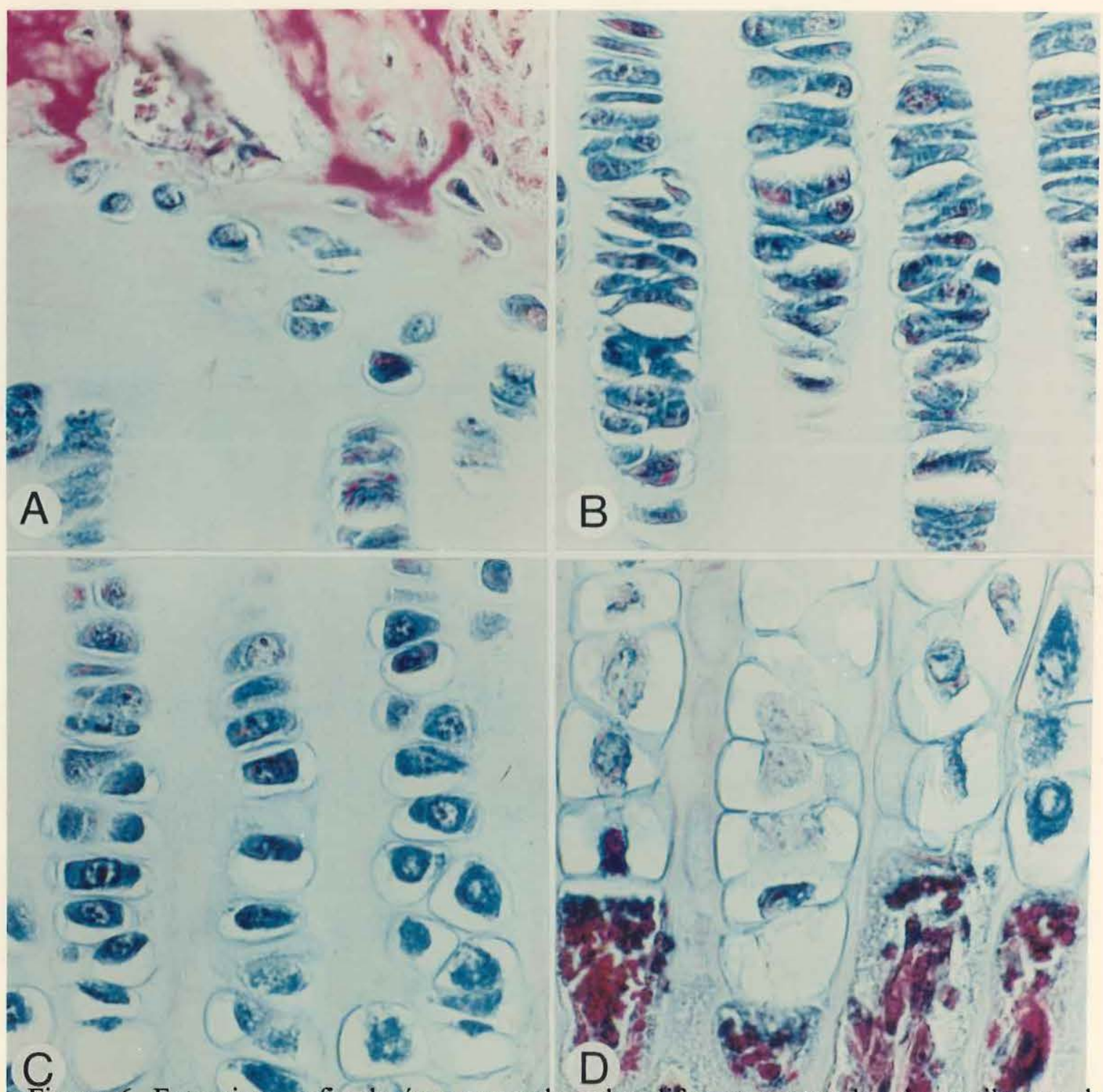

Figura 6. Fotomicrografia da área ocupada pelas diferentes camadas da cartilagem de crescimento que recebeu a placa de pontos eqüidistantes para a contagem de células e matriz (azul alciano-fucsina 160x) 
A técnica para a contagem obedeceu aos seguintes procedimentos:

- as fotos foram escolhidas de maneira aleatória, para que não houvesse identificação das fotos correspondentes ao lado tratado e não tratado, impedindo qualquer indução dos números durante a contagem;

- a placa de pontos regulares foi, então, sobreposta à foto sem posição prédeterminada;

- foi identificada qual estrutura histológica seria registrada, célula ou matriz;

- foi iniciada a contagem registrando todos os pontos que estivessem sobre as células;

- por meio de subtração foi registrado o número de pontos referentes à matriz.

Preliminariamente, foi feito um estudo para que a contagem fosse precisa e confiável identificando o número mínimo de pontos cujo valor fosse representativo e que não experimentasse variação significativa a partir deste momento. Foi selecionado um conjunto de fotos, formando na configuração final a placa de crescimento completa da zona germinativa até a zona calcificada. Para cada foto foi repetida 10 vezes a contagem de pontos e feita uma correlação percentual para as mesmas.

A análise gráfica e os testes estatísticos registraram uma constância na formação da curva indicando que a diferença porcentual não era significativa entre cada momento das coordenadas x (número de pontos) e y (variação porcentual).

A partir deste estudo preliminar foram estudadas todas as fotomicrografias com a simples sobreposição da grade de 200 pontos aferindo, em cada momento, os pontos coincidentes sobre as células e, por subtração, obtido o valor sobre a matriz. 


\subsection{Avaliação pela fluorescência óssea}

A metade anterior da epífise das tíbias de coelhos foi destinada a avaliação pela fluorescência óssea. $\mathrm{O}$ material foi processado sem descalcificação. Foi desidratado em álcool, e processado como descrito a seguir (FROST, 1959; VOLPON, 1985):

1- Cortes seqüenciais do bloco ósseo, no plano frontal, em fatias de mais ou menos 1,0 mm de espessura, com serra especial (SHIMANO et al, 1990).

2- Desidratação em álcool absoluto por três dias, com troca da solução 1 vez por dia;

3- Tratamento em solução de acetona durante 1 dia;

4- Preparo de resina acrílica (Resapol T208 ${ }^{\circledR}$ ) misturando com o catalizador (Monômero de estireno). A solução foi homogeneizada vagarosamente, cuidando-se para não formar bolhas;

5- Cada amostra de osso foi colocada em um pequeno recipiente plástico sendo aí vertida a resina acrílica até que a peça ficasse recoberta. Os frascos foram levados para a estufa a $37^{\circ} \mathrm{C}$, durante um dia, até completar a polimerização;

6- Os blocos de acrílico, com o osso incluído, foram retirados das formas e estocados em ambiente seco e escuro;

7- Depois, foram desgastados manualmente com o atrito em lixas de água com granulações cada vez mais fínas $(320,400,500,600)$, sob fluxo contínuo de água, fazendo-se movimentos circulares lentos e sucessivos e alternando os lados do bloco. Para um desgaste homogêneo a peça foi mobilizada com auxílio de uma lâmina de vidro envolvida por um pedaço de lixa (FROST, 1959).

8- O desgaste foi interrompido quando atingia o osso esponjoso que é frágil e há o risco de ser esfarelado. Para evitar isto, a peça foi lavada em água corrente, desidratada em álcool absoluto e novamente tratada com fina película de acrílico diluído meio-a-meio em acetona para garantir a impregnação de todas 
as cavidades ósseas pela resina. Seguiu-se novo desgaste até que o espécime atingisse uma espessura entre 80 e 100 micrômetros medido com auxílio do micrômetro digital Mitutoyo.

9- A peça foi recortada a um tamanho mínimo e montada em lâmina, com óleo mineral não fluorescente, e parafina selando a periferia da lamínula.

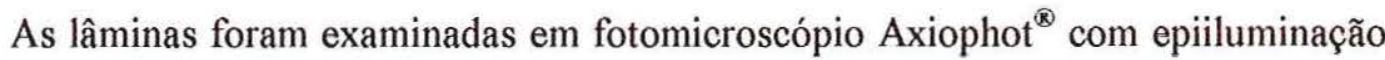
por luz ultra-violeta. Foi utilizado conjunto de filtro 9 (Zeiss $\left.{ }^{8}\right)$, objetiva 5 e aumento de 2,5 vezes. As fotografias foram realizadas em filme preto e branco, ASA 400. Foram obtidas fotografias do tamanho $9 \times 12 \mathrm{~cm}$, com aumento final de 77 vezes, no filme negativo.

A análise dos achados foi realizada pelas fotografias atentando-se para as regiões de fluorescência. O osso neoformado marcado pela tetraciclina fica depositado em uma faixa fluorescente paralela à cartilagem de crescimento e o osso interposto entre esta faixa e a cartilagem de crescimento reflete a osteogênese ocorrida entre a injeção e o sacrificio dos animais (crescimento longitudinal).

A cartilagem de crescimento apresenta-se como uma faixa escura, sem fluorescência alguma. A distância entre a cartilagem de crescimento e a faixa fluorescente foi medida em 4 pontos delimitados previamente. Os resultados foram somados e calculados os parâmetros estatísticos. A comparação foi feita com o lado contralateral. (Fig. 7) 


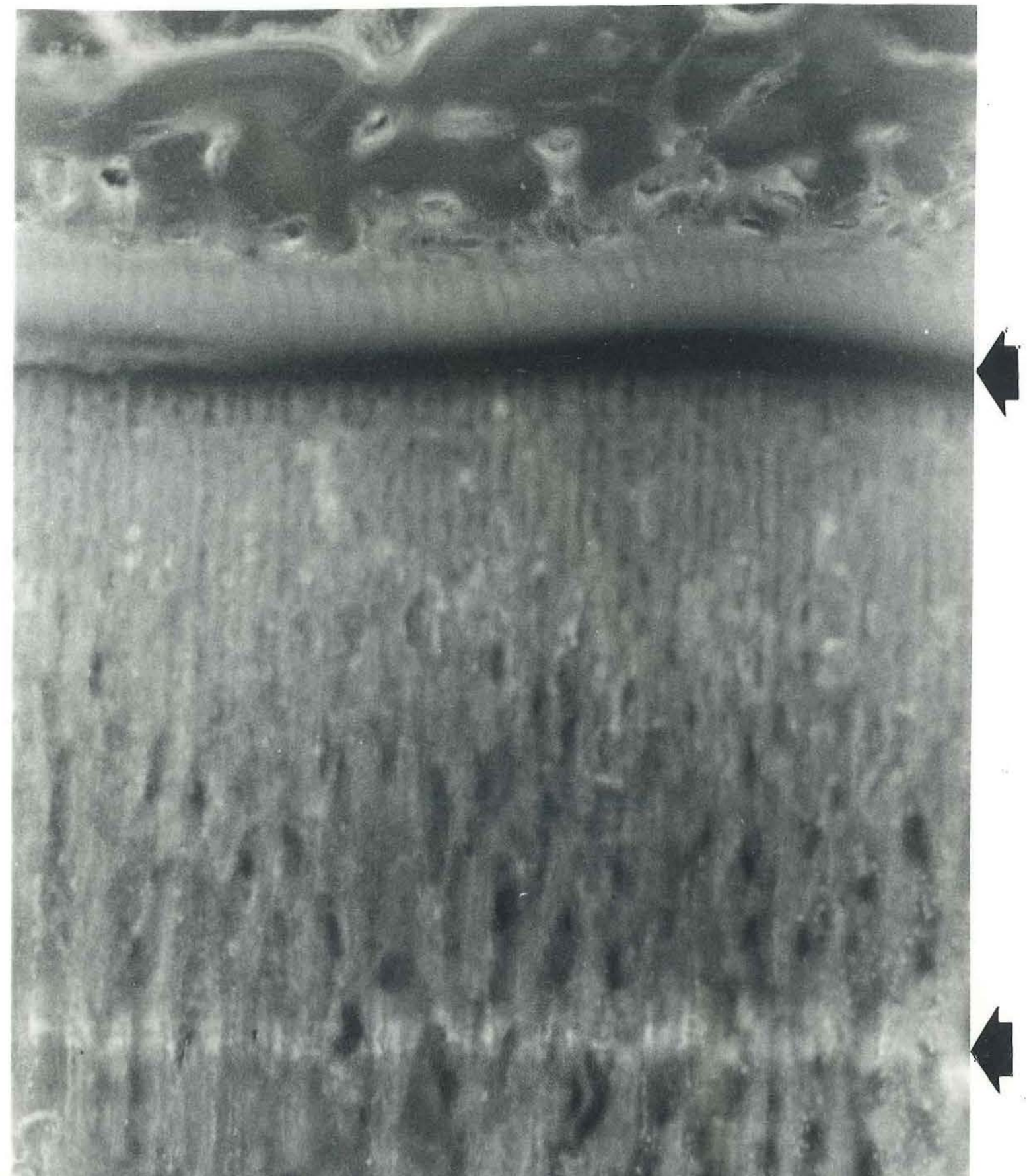

Figura 7. Fotomicrografia com luz ultra-violeta da cartilagem de crescimento proximal da tíbia de coelho, ilustrando a faixa fluorescente de neoformação óssea marcada pela tetraciclina (seta). A cartilagem de crescimento aparece como faixa escura (seta), (77x). 


\subsection{Morfometria Macroscópica}

O grupo constituído de 10 animais para avaliação tardia recebeu o mesmo tratamento do grupo anterior, com a diferença de que só foram sacrificados no final do crescimento esquelético, quando ocorre o desaparecimento da cartilagem de crescimento, o que acontece por volta da décima quarta a décima sexta semana de vida (MASOUD, SHAPIRO, RALPH \& MOSES, 1986).

\subsubsection{Medida radiográfica do ângulo frontal da tíbia}

Após o sacrifício desses animais, os fềmures e tíbias foram isolados e mantidos unidos apenas pela cápsula e ligamento do joelho. Os ossos foram radiografados aos pares, sendo colocados lado a lado, em posição simétrica, em filme de mamografia, com $40 \mathrm{kVp}, 10 \mathrm{mAs}$ e incidência ântero-posterior.

Nas radiografias foi medido o ângulo frontal da tíbia, definido como o ângulo formado entre a linha que tangencia a superficie articular do planalto tibial e a linha do eixo longitudinal do osso. Foi medido o ângulo localizado no quadrante ínfero-medial (Fig.8) 


\section{Medidas do Ângulo Frontal}

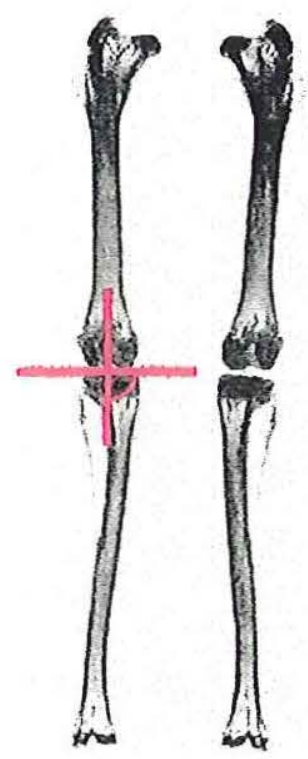

Figura 8. Figura obtida a partir de uma radiografia mostrando o par de fềmures, tíbias e fíbulas ilustrando a obtenção do ângulo frontal da tíbia $(\alpha)$.

\subsubsection{Medidas morfológicas no próprio osso}

Após a realização das radiografias os ossos foram desarticulados. Em seguida, com um paquímetro digital, foram realizadas as medidas de comprimento total do osso e da largura máxima das epífises. 
$\mathrm{O}$ comprimento, no fềmur, foi medido da cabeça femural até a extremidade do côndilo medial. Na tíbia, foi medida a distância entre a superfície medial do planalto tibial até a extremidade do maléolo medial. Ainda na tíbia, foi medida a largura ânteroposterior da epífise. Para cada parâmetro foram realizadas três medidas não seqüenciais e, depois, utilizadas as médias aritméticas para comparação entre o lado tratado e não tratado.

Depois, as tíbias foram seccionadas transversalmente na epífise na região onde se localizara a placa de crescimento. A superficie cruenta do fragmento proximal foi embebida em tinta Nanquim e "carimbada" em uma folha branca, conseguindo-se um desenho fiel da superfície de corte. Este desenho foi levado para uma mesa digitalizadora (Digigraf Tecnology Eletronica Renoir ${ }^{(8)}$ ) e, ponto a ponto, foi demarcado seu contorno. Com o programa “Autocad ${ }^{\circledR ”}$ foram obtidos perímetro e área (Fig. 9). 
Medidas Morfológicas dos Ossos

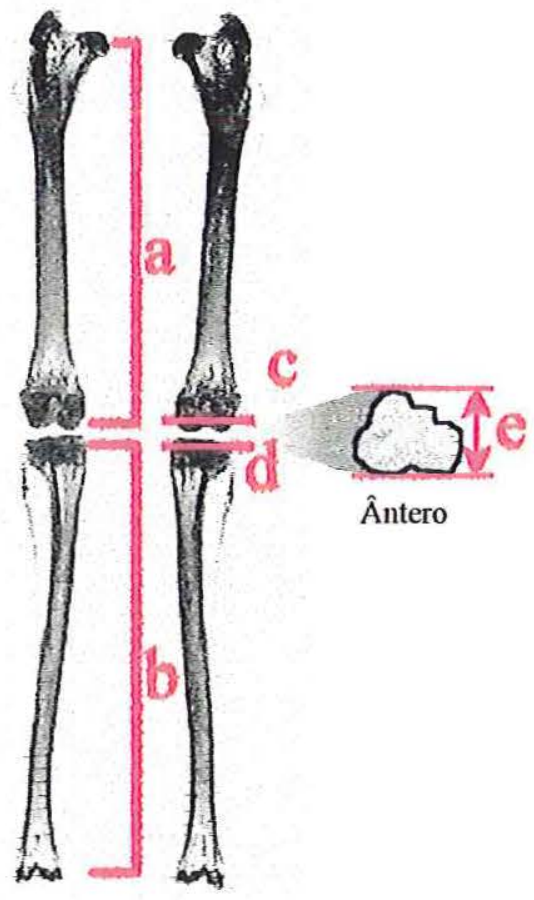

\section{Medida de Área e Perímetro}

ANTERIOR

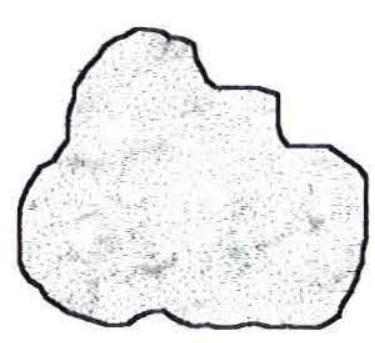

$\uparrow$

POST.

Figura 9. A- Ilustração das medidas do comprimento de fềmur (a), de tíbia (b), de largura da epífise femural (c ), da epífise tibial (d) e do comprimento ântero-posterior (e).

B- Ilustração da medida da área e perímetro da secção transversal na região da epífise tibial 


\subsection{Análise Estatística}

Os parâmetros obtidos com as medidas dos comprimentos dos ossos, área e espessura das camadas e distâncias da faixa de fluorescência foram avaliados pelo teste " $\mathrm{t}$ " pareado de Student.

Os dados obtidos com a contagem de pontos foram avaliados pelo teste de Wilcoxon.

O nível de significância foi estabelecido em $5 \%$ 


\section{RESULTADOS}

\subsection{Estudo Histológico}

Em uma visão panorâmica foi avaliado o formato geral do osso, formato geral da placa epifisária, formato geral do núcleo de ossificação. Com um maior aumento foi examinado o pericôndrio, osso metafisário, osso do núcleo de ossificação, arranjo celular da cartilagem de crescimento e substância intercelular. Em um maior aumento foi possível avaliar as características das células das diferentes camadas da cartilagem de crescimento e características das células do pericôndrio.

A análise histológica qualitativa não evidenciou diferenças morfológicas entre a cartilagem de crescimento do lado tratado e não tratado.

\subsubsection{Morfometria Microscópica}

A tabela I compara os dados obtidos com a morfometria dos cortes histológicos das áreas relativas nos lados tratados e não tratados.

Tabela I.-Medidas da área relativa global e das camadas da secção da cartilagem de crescimento nos lados tratados e não tratados.

\begin{tabular}{|c|c|c|c|c|c|c|c|c|}
\hline & \multirow{2}{*}{\multicolumn{2}{|c|}{$\begin{array}{c}\text { AREA GLOBAL } \\
\left(\mathrm{mm}^{2}\right)\end{array}$}} & \multicolumn{6}{|c|}{ AREA DAS CAMADAS } \\
\hline & & & \multicolumn{2}{|c|}{ GERMINATIVA } & \multicolumn{2}{|c|}{ PROLIFERATIVA } & \multicolumn{2}{|c|}{ HIPERTRÓFICA } \\
\hline & $\bar{T}$ & NT & $\bar{T}$ & NT & $\bar{T}$ & NT & $\bar{T}$ & NT \\
\hline Média & 1839,1 & 1772,3 & 243,9 & 222,6 & 916,5 & 839,4 & 537,0 & 564,4 \\
\hline SD & 265,5 & 323,4 & 95,6 & 63,2 & 159,3 & 143,5 & 116,5 & 136,8 \\
\hline Mediana & 1827,3 & 1794,6 & 224,9 & 207,4 & 961,6 & 806,7 & 497,5 & 572,2 \\
\hline$p$ & \multicolumn{2}{|c|}{0,6003} & \multicolumn{2}{|c|}{0,1979} & \multicolumn{2}{|c|}{0,2228} & \multicolumn{2}{|c|}{0,6900} \\
\hline Interpretação & \multicolumn{2}{|c|}{ não significante } & \multicolumn{2}{|c|}{ não significante } & \multicolumn{2}{|c|}{ não significante } & \multicolumn{2}{|c|}{ não significante } \\
\hline
\end{tabular}


A figura 10 ilustra os resultados da morfometria das áreas globais das cartilagem de crescimento nos lados tratados e não tratados.

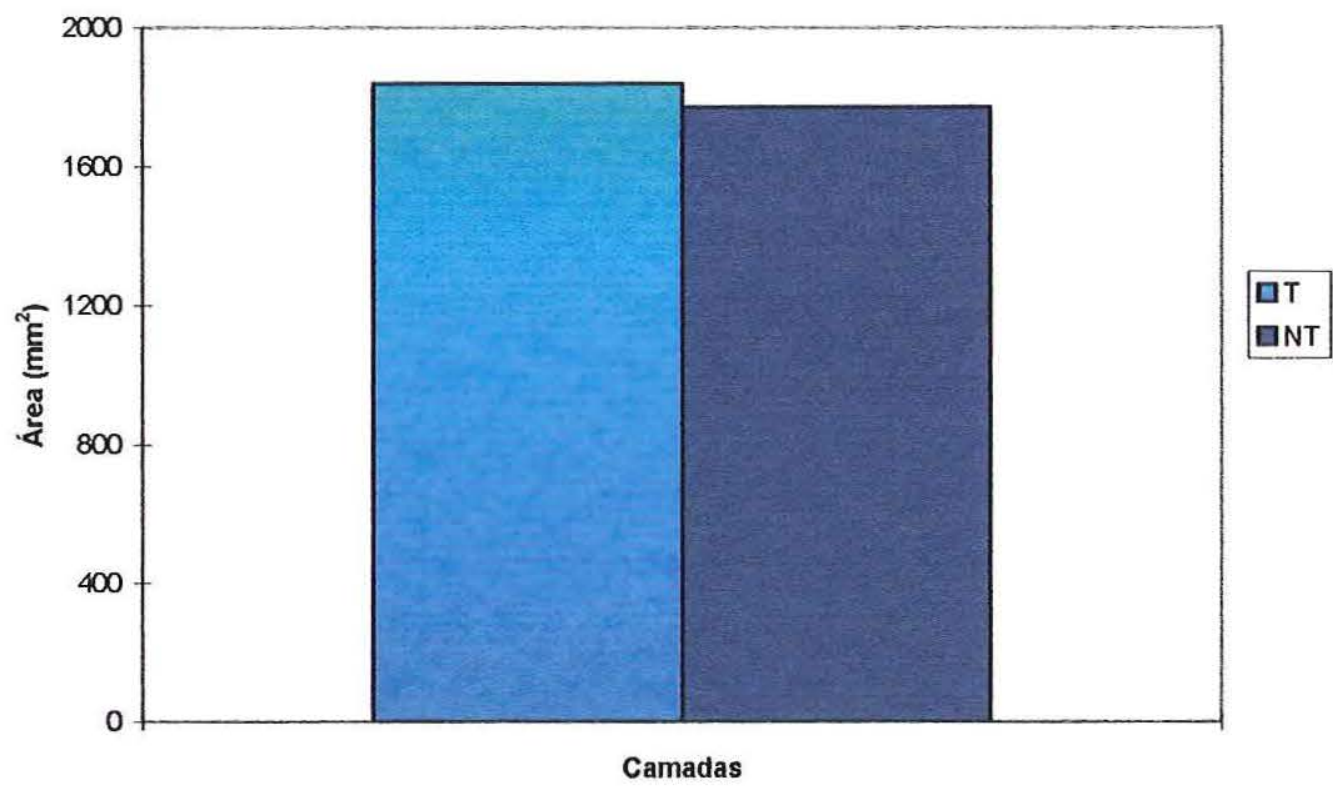

Figura 10. Representação gráfica da área global relativa da cartilagem de crescimento nos lados tratado (T) e não tratado (NT).

A figura 11 ilustra as áreas das diferentes camadas da cartilagem de crescimento no lado tratado e não tratado. 


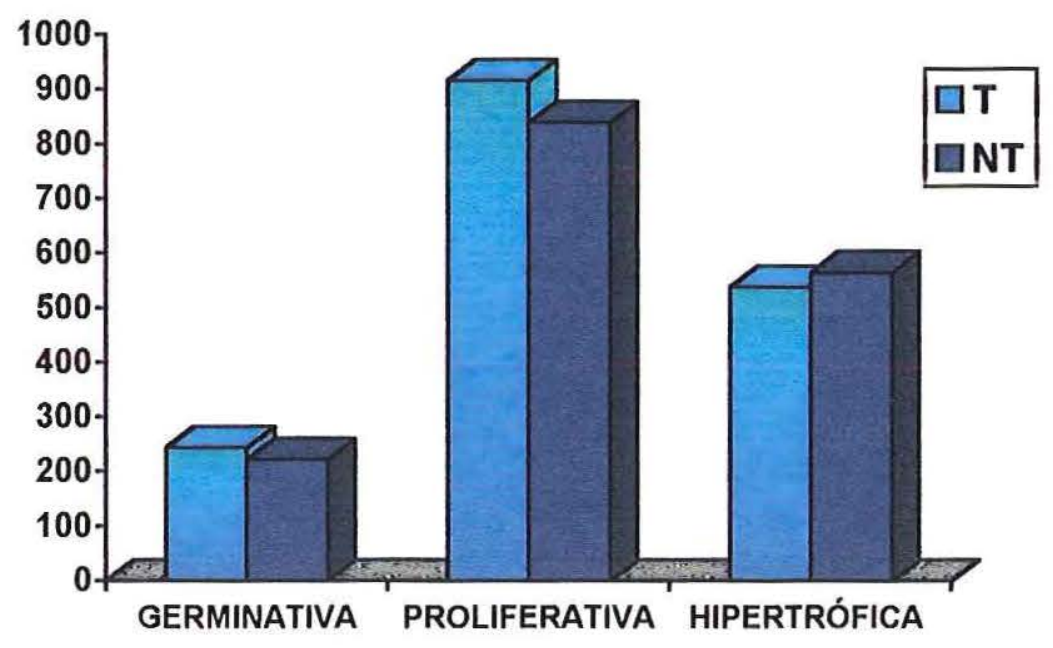

Figura 11. Representação gráfica das áreas das diferentes camadas da cartilagem de crescimento nos lados tratado (T) e não tratado (NT).

A tabela II apresenta os dados obtidos com as medidas da espessura geral da cartilagem e a espessura de cada camada, isoladamente.

Tabela II - Espessura relativa das diferentes camadas da cartilagem de crescimento nos lados tratado e não tratado.

\begin{tabular}{|c|c|c|c|c|c|c|c|c|}
\hline & \multirow{2}{*}{\multicolumn{2}{|c|}{$\begin{array}{l}\text { Espessura } \\
\text { Global (mm) }\end{array}$}} & \multicolumn{6}{|c|}{$\begin{array}{l}\text { Espessura das camadas } \\
(\mathrm{mm})\end{array}$} \\
\hline & & & \multicolumn{2}{|c|}{ GERMINATIVA } & \multicolumn{2}{|c|}{ PROLIFERATIVA } & \multicolumn{2}{|c|}{ HIPERTRÓFICA } \\
\hline & $T$ & NT & $T$ & NT & $T$ & NT & $T$ & NT \\
\hline Média & 45,4 & 43,4 & 6,5 & 6,0 & 25,5 & 22,5 & 14,2 & 15,1 \\
\hline SD & 6,6 & 6,3 & 1,4 & 0,9 & 3,8 & 3,1 & 2,7 & 4,2 \\
\hline Mediana & 45,5 & 44,4 & 6,4 & 6,0 & 25,4 & 22,8 & 13,7 & 15,2 \\
\hline $\mathbf{P}$ & \multicolumn{2}{|c|}{0,5277} & \multicolumn{2}{|c|}{0,2747} & \multicolumn{2}{|c|}{0,7412} & \multicolumn{2}{|c|}{0,5863} \\
\hline Interpretação & não signific & & não signif & cante & Não signi & cante & não sign & ante \\
\hline
\end{tabular}

OBS: $\quad \mathrm{T}=$ tratado

NT= não tratado 
A figura 12 ilustra as espessuras das diferentes camadas nos lados tratado e não tratado, apresentadas na tabela II.

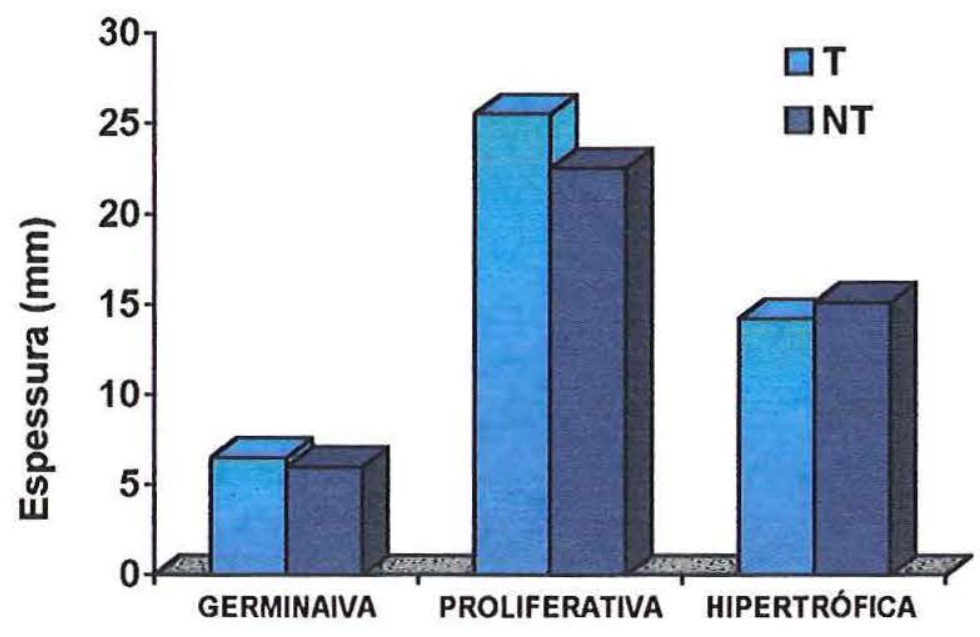

Figura 12. Espessura relativa das camadas da cartilagem de crescimento nos lados tratado (T) e não tratado (NT). 


\subsection{2 . Estudo Quantitativo por Contagem de Pontos}

\subsubsection{Estudo piloto}

Os resultados obtidos pelo estudo prévio da contagem de pontos foi registrado nos gráficos a seguir, os quais garantiram que a contagem de duzentos pontos era equivalente, não demonstrando variação significativa, à contagem de dois mil pontos.

\section{PROPORÇÃO DE MATRIZ}
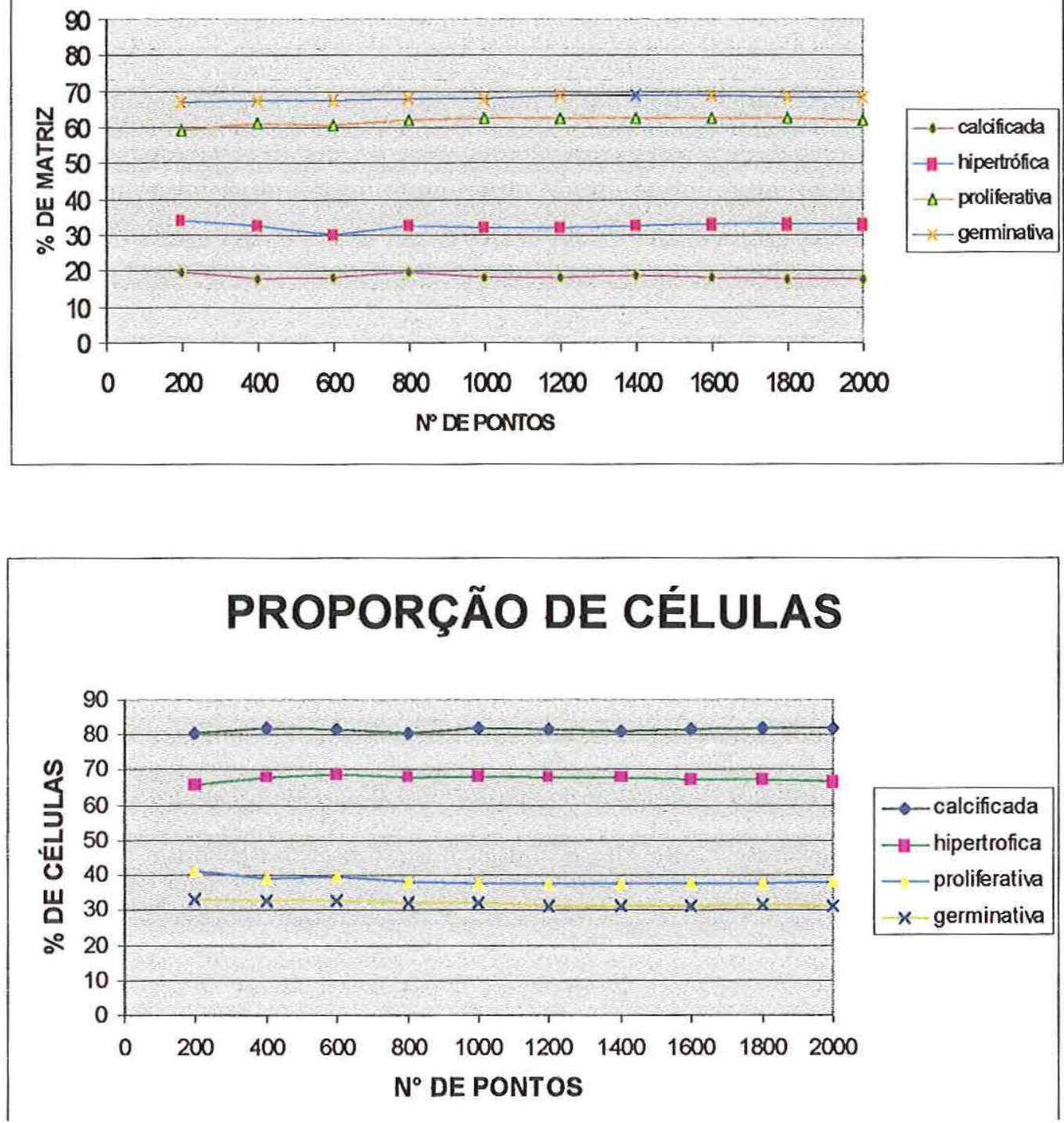
Tabela III - Contagem de pontos nas células nas diferentes camadas da cartilagem de crescimento.

\begin{tabular}{|c|c|c|c|c|c|c|}
\hline & \multicolumn{2}{|c|}{ Germinativa } & \multicolumn{2}{|c|}{ Proliferativa } & \multicolumn{2}{|c|}{ Hipertrófica } \\
\hline & $\mathrm{T}$ & NT & $\mathrm{T}$ & NT & $\mathrm{T}$ & NT \\
\hline Média & 18,6 & 22,4 & 43,4 & 47,4 & 48,7 & 51,8 \\
\hline SD & 5,7 & 5,6 & 12,4 & 7,5 & 11,1 & 11,0 \\
\hline Mediana & 18,3 & 22,8 & 47,3 & 49,0 & 51,8 & 49,8 \\
\hline$p$ & \multicolumn{2}{|c|}{0,125} & \multicolumn{2}{|c|}{0,231} & \multicolumn{2}{|c|}{0,213} \\
\hline Interpretação & \multicolumn{2}{|c|}{ Não significante } & \multicolumn{2}{|c|}{ não significante } & \multicolumn{2}{|c|}{ não significante } \\
\hline
\end{tabular}

NT= lado não tratado

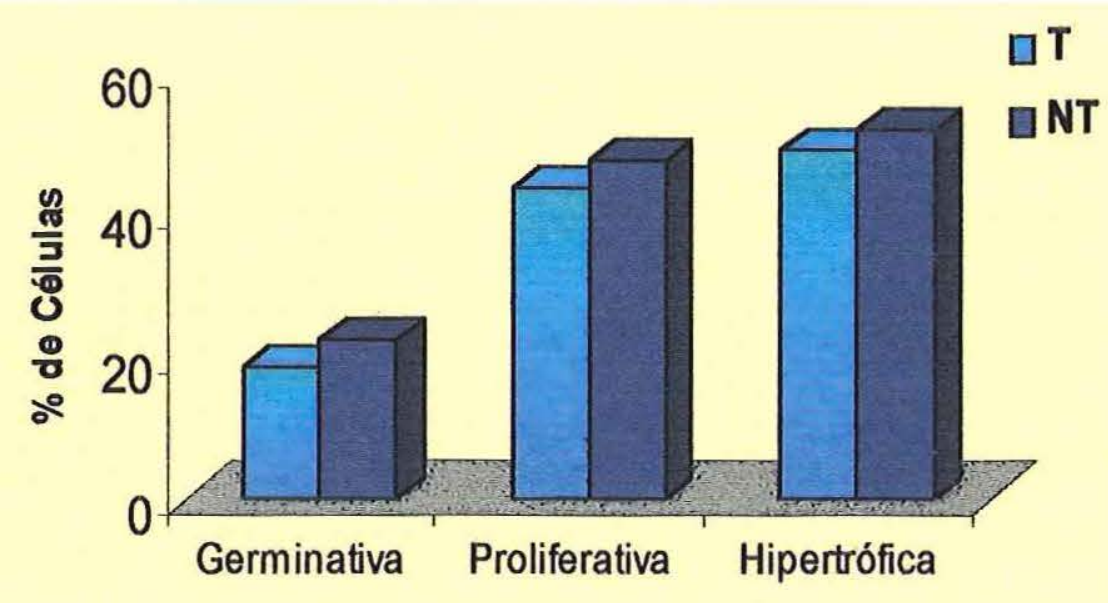

Figura 13. Contagem de pontos nas células nas diferentes camadas da cartilagem de crescimento 
Tabela IV - Contagem de pontos na matriz nas diferentes camadas da cartilagem de crescimento.

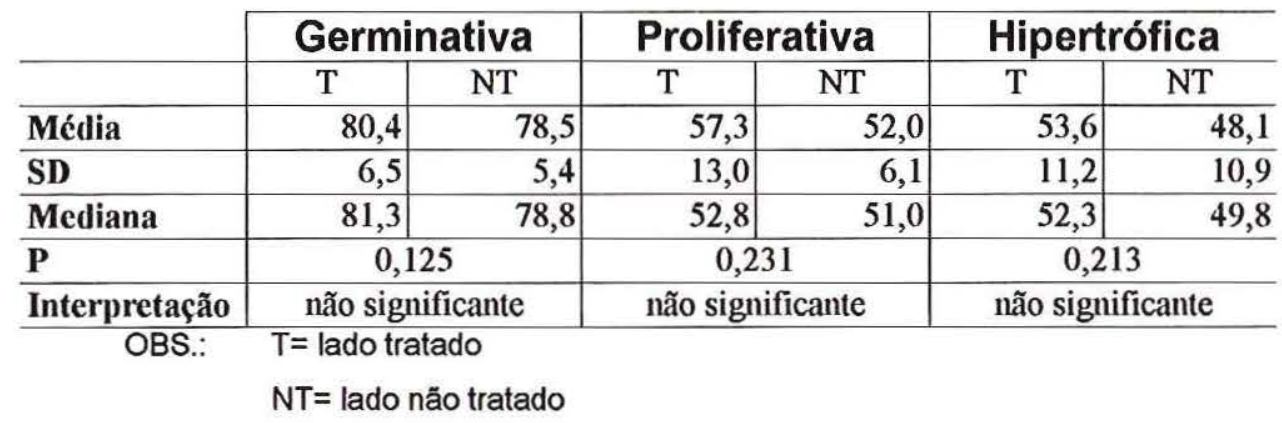

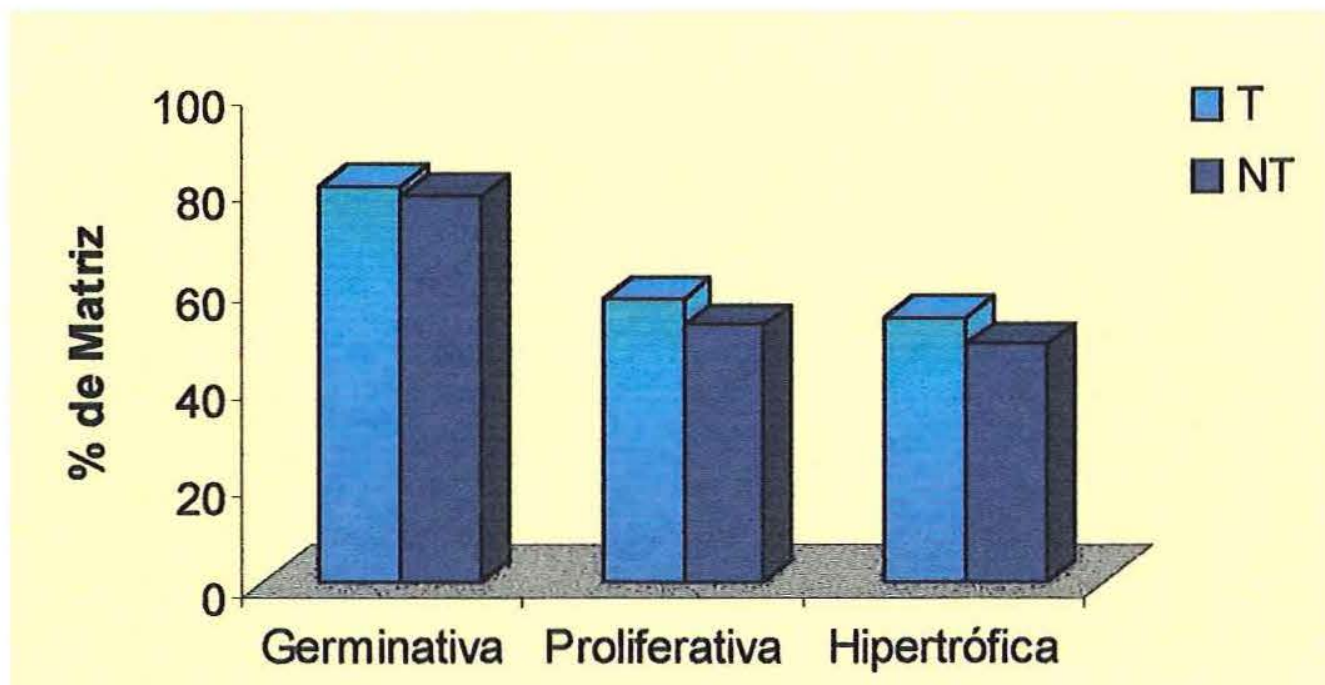

Figura 14 Contagem de pontos na matriz nas diferentes camadas da cartilagem de crescimento 


\subsubsection{Estudo da Fluorescência Óssea}

A tabela $\mathrm{V}$ apresenta as médias aritméticas das distâncias relativas entre a cartilagem de crescimento e a banda fluorescente.

Tabela V-Médias aritméticas das distâncias relativas entre a cartilagem de crescimento e a banda fluorescente.

\begin{tabular}{|c|c|c|c|}
\hline & \multirow[t]{2}{*}{ Parâmetro } & \multicolumn{2}{|c|}{$\begin{array}{c}\text { Distância } \\
\text { (mm) }\end{array}$} \\
\hline & & $\mathrm{T}$ & NT \\
\hline & Média & 65,1 & 60,9 \\
\hline & SD & 2,9 & 5,9 \\
\hline & Mediana & 65,8 & 61,6 \\
\hline & $p$ & & \\
\hline & Interpretação & não & inte \\
\hline
\end{tabular}

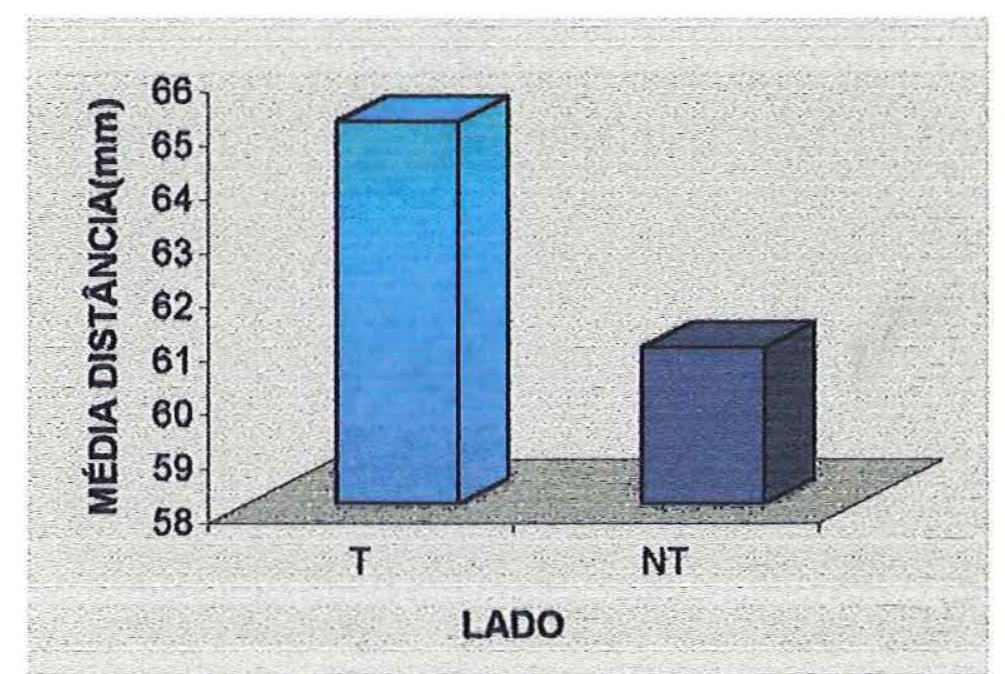

Figura 15. Representação gráfica das médias aritméticas das distâncias relativas entre a cartilagem de crescimento e a banda fluorescente. 


\subsection{4-Estudo da Morfometria Macroscópica}

As médias aritméticas do comprimento e largura epifisária dos fêmures; comprimento, largura e espessura ântero-posterior epifisárias das tíbias, comparadas entre os lados tratado e não tratado estão apresentadas na tabela IV.

TABELA VI. Morfometria macroscópica dos fêmures e tibias.

\begin{tabular}{|c|c|c|c|c|c|c|c|c|c|c|}
\hline & \multicolumn{4}{|c|}{ Fêmur } & \multicolumn{6}{|c|}{ Tíbia } \\
\hline & $\begin{array}{c}\text { Compr. D } \\
(\mathrm{mm})\end{array}$ & $\begin{array}{c}\text { Compr. E } \\
(\mathrm{mm})\end{array}$ & $\begin{array}{c}\text { largura } D \\
(\mathrm{~mm})\end{array}$ & $\begin{array}{c}\text { largura } E \\
(\mathrm{~mm})\end{array}$ & $\begin{array}{c}\text { Compr. D } \\
(\mathrm{mm})\end{array}$ & $\begin{array}{c}\text { Compr. E } \\
(\mathrm{mm})\end{array}$ & $\begin{array}{c}\text { largura D } \\
(\mathrm{mm})\end{array}$ & $\begin{array}{c}\text { largura } \mathrm{E} \\
(\mathrm{mm})\end{array}$ & $\begin{array}{c}\text { ant.post.D } \\
\text { (mm) }\end{array}$ & $\begin{array}{c}\text { ant.post.E } \\
\text { (mm) }\end{array}$ \\
\hline Média & 91,07 & 91,13 & 15,69 & 15,56 & 101,98 & 102,13 & 16,18 & 16,46 & 14,4 & 14,3 \\
\hline $\mathrm{SD}$ & 2,010 & 2,267 & 1,114 & 0,9498 & 2,970 & 2.797 & 0,893 & 0,870 & 0,743 & 0.854 \\
\hline Mediana & 90,7 & 90,78 & 15,33 & 15,25 & 101,01 & 101,14 & 15,91 & 16,07 & 14,13 & 13,98 \\
\hline $\mathrm{p}$ & \multicolumn{2}{|c|}{0.9452} & \multicolumn{2}{|c|}{0,7714} & \multicolumn{2}{|c|}{0,9047} & \multicolumn{2}{|c|}{0,4682} & \multicolumn{2}{|c|}{0.7746} \\
\hline Interpretação & \multicolumn{2}{|c|}{ não significante } & \multicolumn{2}{|c|}{ não significante } & \multicolumn{2}{|c|}{ não significante } & \multicolumn{2}{|c|}{ não significante } & \multicolumn{2}{|c|}{ não significante } \\
\hline
\end{tabular}


A tabela VII apresenta as medidas dos perímetros e áreas da seç̧ão transversal epifisiometafisário das tíbias.

Tabela VII -Área e perímetro da secção transversal epifisiometafisário das tíbias.

\begin{tabular}{lcccc}
\hline & Perímetro D(mm) & Perímetro E $(\mathbf{m m})$ & Area D $\left(\mathbf{m m}^{2}\right)$ & Area E $\left(\mathbf{m m}^{2}\right)$ \\
\hline Média & 53,76 & 52,8 & 166,05 & 164,49 \\
\hline SD & 2,32 & 3,495 & 19,38 & 18,89 \\
\hline Mediana & 53,09 & 51,81 & 163,37 & 154,4 \\
\hline P & \multicolumn{2}{c}{0,4575} & \multicolumn{2}{c}{0,5603} \\
\hline Interpretação & \multicolumn{2}{c}{ não significante } & não significante \\
\hline
\end{tabular}

A tabela VIII apresenta os valores médios do ângulo frontal da tíbia nos lados tratado e não tratado.

Tabela VIII - Medida radiológica do ângulo frontal da tíbia

\begin{tabular}{lcc}
\hline & D (graus) & $\mathbf{E}$ (graus) \\
\hline Média & 90 & 89,6 \\
\hline SD & 1,0 & 1,56 \\
\hline Mediana & 90 & 90 \\
\hline P & \multicolumn{2}{c}{0,5238} \\
\hline Interpretação & \multicolumn{2}{c}{ não significante } \\
\hline
\end{tabular}




\section{DISCUSSÃO}

O ultra-som é utilizado, há vários anos, como ferramenta terapêutica, representando um dos recursos eletroterápicos mais empregados na fisioterapia (HAAR et al, 1987). Inicialmente era usado na forma contínua com base nos efeitos térmicos, com o objetivo de tratar processos patológicos diversos como cicatrização tecidual, liberação de aderências e processos inflamatórios. No entanto, as contra-indicações também eram temidas.

Paralelamente a essas evidências, pesquisas, as mais diversas, foram se desenvolvendo com o objetivo de identificar as propriedades biofísicas da atuação das ondas ultra-sônicas sobre as estruturas orgânicas. Associadas aos estudos do ultra-som de forma contínua, as atenções passaram a ser dirigidas, em torno de 1960, à forma de transmissão de ondas pulsadas, que também ofereciam efeitos térmicos, porém com uma significativa amenização no potencial lesivo devido à própria configuração do tipo de estimulação, formando ciclos de atividade seguidos de períodos de silêncio.

Em 1987, DYSON publicou um artigo em que registrava a necessidade de mais investigações para o entendimento das reações orgânicas desencadeadas pelo ultra-som terapêutico. Concordamos com essa posição, uma vez que o uso na prática clínica freqüentemente obedece a padrões empíricos.

As principais contra-indicações da aplicação do ultra-som referem-se ao útero grávido, lesões malignas, anormalidades vasculares incluindo trombose e arterosclerose e olhos (HOOGLAND, 1986)

Para aplicação de ondas ultra-sônicas nas vizinhanças do disco epifísário existe a grande precaução e, em alguns artigos, a contra-indicação (DYSON, 1985 ; HOOGLAND, 1986) por se temer alguma lesão que possa interferir no crescimento ósseo. Assim, crianças e adolescentes com processos inflamatórios epifisários ficam excluídos do tratamento com ultra-som quando o processo patológico situa-se nas adjacências do disco epifisário. 
O temor de que o ultra-som possa ser potencialmente danoso advém da vulnerabilidade da placa de crescimento aos traumatismos e infecções (GOMES \& VOLPON, 1991, 1993), pela nobreza de suas funções, i.e., crescimento global e alinhamento do osso longo e, também, pelo constatação da ação das ondas ultra-sônicas sobre outros tecidos. Um dos efeitos bem conhecidos do ultra-som é o térmico (LEHMANN, \& JOHNSON 1958) que, além de algumas manifestações menores, pode provocar cavitações por formação de bolhas que podem permanecer intactas por muitos ciclos (cavitação estável) ou entrar em colapso violento (cavitação transitória), elevando mais a temperatura local (WELLS, 1977). O colapso das bolhas libera energia que pode romper ligações moleculares, produzir radicais livres, causar alterações químicas e lesar o tecido adjacente (APFEL,1982).

Assim, esta investigação buscou pesquisar a interferência das ondas ultra-sônicas sobre a atividade da placa de crescimento, colocando-se entre aquelas que buscam pesquisar os efeitos promovidos pelo ultra-som no organismo humano. Nossos resultados então, podem auxiliar na evolução do conhecimento do ultra-som como recurso terapêutico fazendo beneficiar o fisioterapeuta e contribuindo com o tratamento de crianças e adolescentes.

Nesta investigação, o coelho foi escolhido como animal de experimentação por apresentar linhagem relativamente pura, com crescimento ósseo bem conhecido e rápido (MASOUD et al., 1986) e pelo fácil manuseio em laboratório.

A região proximal da tíbia foi selecionada por ter localização subcutânea, o que garantiu segurança no posicionamento do transdutor, tendo como referência a interlinha articular, facilmente identificável, e pela sua face medial ser aplanada. A placa epifisária proximal da tíbia foi selecionada como região de estudo por ser macroscópica e microscopicamente uniforme, o que favoreceu a análise histológica.

Com relação ao nosso material e métodos concluímos que seria necessária uma analogia, a mais fidedigna possível do que ocorre na prática clínica. Afinal, o nosso objetivo desde o princípio foi a correlação direta da prática experimental com a clínica contribuindo, assim, com a evolução das pesquisas dentro da Fisioterapia. 
Selecionamos o ultra-som pulsado pelas características de produção de efeitos físiológicos térmicos com grande atenuação de processos lesivos. A intensidade selecionada para a estimulação foi o fundo de escala, a quantidade máxima de intensidade oferecida pelo aparelho, atingindo, assim, o nível no qual supostamente ocorressem riscos de danos teciduais (DYSON et al,1968).

O tempo de 5 minutos é suficiente para gerar a ocorrência de efeitos térmicos e não térmicos (DYSON et al,1968) para pequenas áreas, como a região medial do terço proximal de tíbia de coelho. Após o sacrifício dos animais, a retirada dos ossos e o processamento do material foi por nós executado assegurando, assim, o preparo cuidadoso e padronizado.

Nossa análise foi microscópica qualitativa e quantitativa. A análise qualitativa foi avaliada pela histologia com luz comum procurando alterações nas zonas da placa de crescimento.

Com a escassez de registros sobre a atuação do ultra-som na placa de crescimento e com o crescente receio de seu uso, vimos a necessidade de ser conduzido um estudo para a obtenção de dados quantitativos. A análise quantitativa foi realizada pelo estudo morfométrico da placa de crescimento, avaliando sua área geral, espessura, área específica de cada zona da placa de crescimento e um estudo morfométrico quantitativo de contagem de pontos para a formação celular específica de cada camada. A função mais nobre da cartilagem de crescimento é exatamente o crescimento ósseo que ocorre de maneira longitudinal e resulta da multiplicação e diferenciação das células cartilaginosas. Assim, pareceu-nos, que o aspecto e parâmetros morfológicos micro e macroscópicos do disco epifisário pudessem refletir algum dano causado pelo ultra-som.

Por outro lado, com a técnica da fluorescência foi possível avaliar funcionalmente a neoformação óssea.

A análise morfométrica da área epifisária foi selecionada para verificar se poderia haver alguma interferência com a remodelação óssea que é intensa nesta região.

Sentimos necessidade de incluir um subgrupo adicional para ser seguido até o final do crescimento pois sabe-se, da clínica, que algumas manifestações de lesão da cartilagem de crescimento só ficam caracterizadas na época da maturação esquelética 
(VOLPON, comunicação pessoal, 1997). Todos nossos resultados não mostraram diferença alguma que pudesse refletir alterações provocadas pelo ultra-som na cartilagem de crescimento. De certa forma, nossos resultados contrapõem-se àqueles obtidos por Wiltink et al (1995) que identificaram um efeito positivo do ultra-som pulsado em cultura de cartilagem, no sentido de promover o comprimento das células proliferativas (aumentando o tamanho desta zona). Cremos que seja difícil a comparação dos resultados dos dois trabalhos. Primeiro, os autores mencionados trabalharam com cultura de células o que pode não refletir o comportamento das mesmas células quando participantes do osso "in vivo." Segundo, os mesmos autores avaliaram os resultados em curto período de tempo, o que não significa que os efeitos obtidos sejam duradouros. No entanto, identificamos uma crítica à nossa metodologia. Apesar de termos estabelecido os parâmetros de estimulação no aparelho, não foi possível qualificar ou quantificar a energia ultra-sônica recebida no disco epifisário. Entretanto, levando em consideração de que esta é a situação que se tem na prática clínica, não há invalidação dos nossos resultados.

Os resultados apresentados na Tabela I, onde analisamos a área global e área por camadas mostraram números próximos que, analisados estatisticamente, não apresentaram valores significativamente diferentes. Dando seqüência à análise de nossos resultados, a Tabela II que apresenta a espessura global e de camadas, também não apresentou diferença significativa e, assim sucessivamente, para as Tabelas $\mathrm{V}$ (fluorescência óssea), VI (morfometria macroscópica), VII (área e perímetro), e VIII (medida do ângulo frontal).

Quando analisados os dados da contagem de pontos para as células da placa de crescimento, nos deparamos com números que poderiam sugerir diferença, no entanto, quando levados para a análise estatística com o teste de Wilcoxon, novamente a diferença foi não significante.

Em resumo nossos resultados, quer macro ou microscópicos, quer recentes ou obtidos no final do crescimento levam a uma única conclusão: não houve indício de que o ultra-som, na dose e técnicas empregadas, tenha provocado alguma alteração transitória ou permanente na cartilagem de crescimento. 
Os resultados histológicos nos deram sinais que as temidas alterações provavelmente não ocorreram. Contudo, isto não exclui a necessidade de um aprofundamento na investigação sobre os efeitos do ultra-som na cartilagem de crescimento. Um refinamento deste estudo poderia ser realizado com a avaliação cromossômica após a aplicação do ultra-som, como (HADDAD,1992) realizou para o ultra-som de baixa intensidade aplicado em testículos de ratos. Esta é uma proposta para investigação futura. 


\section{Conclusão}

Sob as condições experimentais desta pesquisa chegamos à conclusão que a aplicação do ultra-som não provocou manifestações que pudessem ser identificadas como alterações morfológicas na cartilagem de crescimento. 


\section{Resumo}

A aplicação do ultra-som terapêutico é contra-indicada nas adjacências da cartilagem de crescimento pelo temor de que possa provocar algum efeito lesivo. Entretanto, não há confirmação experimental ou clínica de que este efeito possa ocorrer. Foi objetivo deste trabalho investigar uma possível ação do ultra-som terapêutico aplicado na região da cartilagem de crescimento.

Foram usados coelhos albinos da raça Nova Zelândia de $1 \mathrm{~kg}$ de peso, fềmeas, que foram distribuídas em 2 grupos, sendo que em ambos foi aplicado ultra-som na cartilagem de crescimento proximal da tíbia direita e a tíbia esquerda mantida como controle. No grupo 1 (20 coelhas), os animais foram sacrificados 3 dias após o término da aplicação do ultra-som e a cartilagem de crescimento foi avaliada morfometricamente do ponto de vista histológico e com microscopia de luz ultra-violeta para o estudo da neoformação óssea marcada com tetraciclina. No grupo 2 (10 coelhas) os animais foram mantidos vivos até o final do crescimento e realizada a morfometria macroscópica pelo alinhamento frontal dos joelhos e região proximal da tíbia pelo uso de radiografias e medidas diretas nas peças.

A forma de ultra-som utilizada foi a pulsada, frequência de $1 \mathrm{MHz}$, pulso de 2:8, e intensidade $20 \%$ do valor nominal apresentada no potenciômetro do aparelho.

A morfometria, tanto da espessura global da cartilagem, como por camadas e pela contagem de células não mostrou diferença entre os lados. A avaliação do crescimento ósseo também não mostrou diferenças. Da mesma forma, a morfometria macroscópica foi igual entre os lados.

Como resultado final, não foram observadas diferenças entre o lado tratado e lado controle. 


\section{SUMMARY}

The therapeutic ultrasound is not apllied to areas that one close to the growth plate to avoid some injury to that structure . Nevertheless, there is neither experimental nor clinical evidence that supports such fear. Based on this premise this investigation was designed to study some possible action of the application of therapeutic ultrasound on the growth plate, using morphometric analysis.

White New Zealand female rabbits, weighning $1 \mathrm{~kg}$ were used and divided into two groups according to the follow up period.

In the first group (20 rabbits) the animals were killed 3 days after the completing of ultrasound application and the growth plate was evaluated with histological morphometric methods and with tetracycline bone labeling. In the second group (10 rabbits) the animals were killed after the completing skeletal maturit and the analysis was made with X-Ray (knee frontal angle) and diret measurements of the proximal tibia in the specimens.

Pulsed ultrasound with frequency of $1 \mathrm{MHz}, 2: 8$ of pulse was applied on the proximal part of the right tibia for all the animals. The left side was kept as a control.

The morphometric analysis of the thickness of the growth cartilage as a whole and for its different layers and the cell counting did not show any difference between the sides. The bone growth was the same on both tibias and the macroscopic morphometry did not show any difference between the sides as well.

It was concluded that no differences was observed between the treated and the control side. 
8.

\section{REFERÊNCIA BIBLIOGRÁFICA}

ALDES, J.H. (1956). Ultrasonic Radiation in the Treatment of Epicondylitis. G.P., v13, n6, p89-96.

APFEL, R.E. (1982). Acoustic cavitation: a possible consequence of biomedical uses of ultrasound. Br. J. Cancer, v 45, p 140-175.

BALDES, E.J.; HERRICK,J.F.; STROEBEL,C.F. (1958). Biological Effects of Ultrasound. Am. J. Phys. Med. Rehabil.,v37, p111-121.

BRIGHT, R.W.; BURSTEIN, A W.; ELMORE, S.M. (1974). Epiphyseal plate cartilage.

J. Bone Joint. Surg., 56 A, n4, p688-703.

BRIGHTON, C.T. (1978). Structure and Function of the growth plate. Clin. Orthop.,v136, p22-32.

DUARTE, L.R.; XAVIER, C.A.M. ( 1983 ). Estimulação ultra-sônica do calo ósseo. Rev Bras. Ortop., v18, n3, p73-80.

DYSON, M. (1982). Non-Thermal cellular effects of Ultrasound. Br. J. Cancer, v45, p165-171.

DYSON, M. (1985). Therapeutic Applications of Ultrasound in Biological effects of ultrasound. Churchill Livingstone, new York, Edinburgh, London and Melbourne, p121-133.

DYSON, M. (1987). Mechanisms involved in Therapeutic Ultrasound. Physiotherapy, v73, n3, p116-120.

DYSON, M.; POND, J.B.; JOSEPH, J. ; WARWICK, R. (1968). The stimulation of tissue regeneration by means of ultrasound. Clin.Sci., n35, p273-285.

DYSON, M; SUCKLING, J. (1978). Stimulation of tissue repair by Ultrasound: A survey of the Mechanisms involved. Physiotherapy, v64, n4, p105-108.

FOUNTOURA FILHO, C. (1996). Ensaio de cisalhamento na placa de crescimento proximal da tíbia de ratos em idades diferentes: estudo comparativo entre tíbias ensaiadas a fresco e após congelamento. Dissertação Mestrado; apresentada à

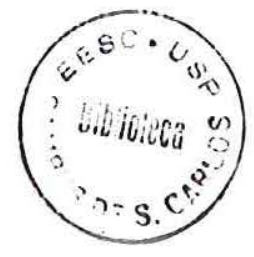


Faculdade de Medicina de Ribeirão Preto da Universidade de São Paulo, Departamento de Cirurgia, Ortopedia, e Traumatologia.

FROST, H.M. (1959). Preparation of thin undecalcified bone sections by rapid manual method. Stain Techonol. 33:273-277.

FROST, H.M. (1963). Measurement of human bone formation by means of tetracycline labeling. Canc. J. Bioch. Phys. 41:31.

FUIRINI, N.Jr. (1996). Manual de Ultrasom

GAM, A.N.; JOHANNSEN, F. (1995). Ultrasound therapy in musculoskeletal disorders: a meta-analysis. Pain, Elsevier Science, v63, p85-91.

GOMES, L.S.M.; VOLPON, J.B. (1991). Estudo experimental do processo de reparação das lesões epifisárias tipo III e IV de Salter \& Harris. Rev Bras. Ortop. 26: 161.

GOMES, L.S.M.; VOLPON, J.B. (1993). Experimental physeal fracture separation treated with rigid internal fixation. J. Bone Joint. Surg., 75 A: 1756-1764.

GOMES, L.S.M.; VOLPON, J.B. (1988). Traumatic separation of the epiphyses. Experimental study in rabbits. Clin. Orthop. 236:286-295.

GONÇALVES, R.P.; OLIVÉRIO, L.G. (1965). Electrical decalcification of bone. Mikroskopie, 20:154.

HAAR, G.R. (1978). Basic Physics of Therapeutic Ultrasound. Physiotherapy, v64, n4, p100-102.

HAAR, G.R.; DYSON, M; OAKLEY, E.M. (1987). The use of ultrasound by physiotherapists in Britain,1985. Ultrasound in Med. Biol., v13, n10, p659-663.

HADDAD, S. (1992). Estímulo do testículo de ratos pré-puberes, púberes e adultos com ultra-som pulsado de baixa intensidade. Dissertação Mestrado; apresentada à Área de interunidades EESC/FMRP-USP.

HAM, A W. (1967). Histologia. 3 ed., Editora Guanabara Koogan S.A.; Rio de Janeiro.

HASS, S.L. (1917). The localization of the growing point of the epiphyseal cartilage plate of bones. Am. J. Orthop., v15, p563-565.

HASS, S.L. (1919). The changes produced in the growing bone after injury to the epiphyseal cartilage plate. Am. J. Orthop., v.1, p67.

HILL, C.R. (1968). The British Journal of Radiology. J. Radiol., v41, p561-569. 
HOOGLAND, R. (1986). Terapia ultrasónica. Enraf-Nonius, p5-35.

IANNOTTI, J.P. (1990). Growth plate physiology and pathology. Orthop. Clin. North Am., January, v21, n1, p1-15.

INGALLS, T.H. (1941). Epiphyseal growth: normal sequence of events at the epiphyseal plate. Endocrinology, November,v29, p710-720.

KEMBER, N.F. (1960). Cell division in endochondral ossification: a study of cell proliferation in rat bones by the method of tritiated thymidine autoradiography. J. Bone Joint Surg., v42B,p824.

KITCHEN, S.S.; PARTRIDGE, C.J. (1990). A review of Therapeutic Ultrasound. Physiotherapy, v76, n10, p593-598.

LEHMANN, J.F.; DeLATEUR, B.J.; SILVERMAN, D.R. (1966). Selective Heating Effects of Ultrasound in Human Beings. Arch. Phys. Med. Rehabil., v47, n6, p331339.

LEHMANN, J.F.; GUY, A.W. (1972). Ultrasound therapy. In Reid,J.. and Sikov M.. Interation of Ultrasound and Biological Tissues. Government Printing Office. Washington, p141-152.

LEHMANN, J.F.; JOHNSON, E.W. (1958). Some factors influencing the temperature distribution in thighs exposed to ultrasound. Arch. Phys. Med. Rehabil., p347-356.

LIANZA, S. (1982). Medicina de Reabilitação. 2ed, Guanabara Koogan, Rio de Janeiro, R.J..

LOVERIDGE, N.; FARQUHARSON, C. (1993). Studies on growth plate chondrocytes in situ: cell proliferation and differentiation. Acta Paediatr. Suppl., 391,p 42-48.

MASOUD, I.; SHAPIRO, F.; KENT, R.;MOSES, A. (1986). A longitudinal study of the growth of the New Zealand white rabbit: Cumulative and biweekly incremental growth rates for body length, body weight, femoral length and tibial length. J. Orthop. Res., 4:221-231.

McDIARMID, T.; BURNS, P. (1987). Physiotherapy, v73, n4, p156-161.

OKUNO, E. (1982). Física para Ciências Biológicas e Biomédicas. Harper \& Rown do Brasil, S.P., cap. 16. 
PATRICK, M. (1978). Applications of Therapeutic Pulsed Ultrasound. Physiotherapy, v64, n4, p103.

PURAMEN, J. (1966). Reorganization of fresh and preserved bone transplants. An experimental study in rabbits using tetracycline labeling. Acta Orthop. Scand. Suppl. 92.

SALTER, R.B.; HARRIS, R. (1963). Injuries involving the epiphyseal plate. J. Bone Joint Surg.,45 A.

SHIMANO, A.C.; PAULIN, J.B.P.; TERRA, O ; PEREIRA, L.H.A. (1990). : Serra frezadora espacial com movimentos em (x,y,z). Rev Bras. de Eng. , v7, n1, p601-604. SILVA, O. (1994). Ultra-som aplicado à Medicina, Apostila de Curso.

TRUETA, J. ; MORGAN, J.D. (1960). The vascular contribuition to osteogenesis. J. Bone Joint. Surg., 42B: 97.

TRUETA, J.; AMATO, J.P. (1969). The vascular contribution to osteogenesisIII: changes in the growth cartilage caused by experimental induced ischaemia. J. Bone Joint Surg., v42 B, p 571.

VOLPON, J.B. (1985). A marcação do osso com substâncias fluorescentes. Rev Bras. Ortop., 20:205-207.

WEIBEL, E.R.; KISTLER, G.S.; SCHERLE, W.F. (1966). Practical Stereological Methods for Morphometric Cytology. J. Cell Biol., v30, n1, p23-38.

WEISS, L. (1983). Histology cell and tissue biology. 5 ed; Elsevier Biomedical, New York.

WELLS, P.N.T. (1977). Biological effects. In Biomedical ultrasonics. London, Academic Press, p 421- 469.

WILTINK, A.; NIJWEIDE, P.I.; OOSTERBAAN, W.A.; HEKKENBERG, R.T.; HELDERS, P.J. (1995). Effect of therapeutic ultrasound on endochondral ossification. Ultrasound Med. Biol., v21, n1, p 121-127. 